
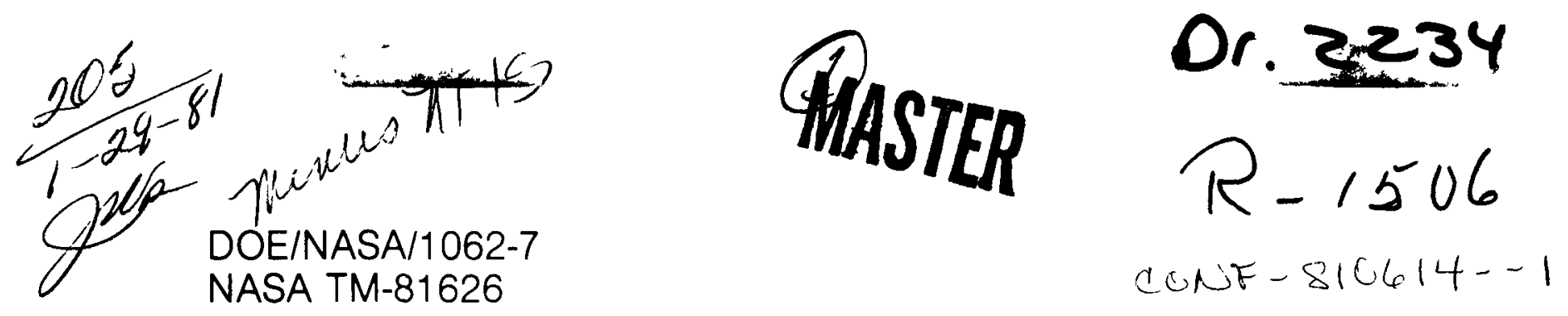

\title{
High Power Densities from High-Temperature Material Interactions
}

James F. Morris

National Aeronautics and Space Administration

Lewis Research Center

Work performed for

U.S. DEPARTMENT OF ENERGY

Fossil Energy

Office of Coal Utilization

Prepared for

Sixteenth Thermophysics Conference, High

Temperature Material Session, sponsored by

American Institute of Aeronautics and Astronautics

Palo Alto, California, June 23-25, 1981 


\section{DISCLAIMER}

This report was prepared as an account of work sponsored by an agency of the United States Government. Neither the United States Government nor any agency Thereof, nor any of their employees, makes any warranty, express or implied, or assumes any legal liability or responsibility for the accuracy, completeness, or usefulness of any information, apparatus, product, or process disclosed, or represents that its use would not infringe privately owned rights. Reference herein to any specific commercial product, process, or service by trade name, trademark, manufacturer, or otherwise does not necessarily constitute or imply its endorsement, recommendation, or favoring by the United States Government or any agency thereof. The views and opinions of authors expressed herein do not necessarily state or reflect those of the United States Government or any agency thereof. 


\section{DISCLAIMER}

Portions of this document may be illegible in electronic image products. Images are produced from the best available original document. 


\section{NOTICE}

This report was prepared to document work sponsored by the United States Government Nelther the United States nor its agent, the United States Department of Energy, nor any Federal employees, nor any of their contractors, subcontractors or their employees, makes any warranty, express or implied, or assumes any legal liability or responsibility for the accuracy, completeness, or useluiness of any information. apparatus, product or process disclosed, or represents that its use would not infringe privately owned rights 


\section{High Power Densities from High-Temperature Material Interactions}

James F. Morris

National Aeronautics and Space Administration

Lewis Research Center

Cleveland, Ohio 44135

Work performed for

U.S. DEPARTMENT OF ENERGY

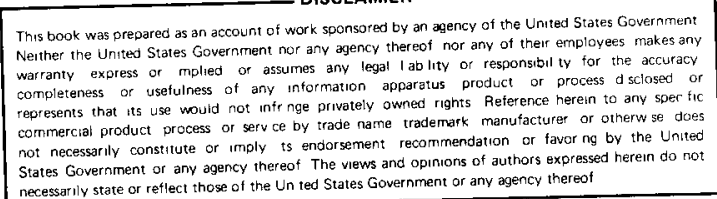

Fossil Energy

Office of Coal Utilization

Washington, D.C. 20545

Under Interagency Agreement EC-77-A-31-1062

Prepared for

Sixteenth Thermophysics Conference, High

Temperature Material Session, sponsored by

American Institute of Aeronautics and Astronautics

Palo Alto, California, June 23-25, 1981 
HIGH POWER DENSITIES FROM HIGH-TEMPERATURE MATERIAL INTERACTIONS*

\author{
James F. Morris \\ National Aeronautics and Space Administration \\ Lewis Research Center \\ Cleveland, Ohro
}

\section{Abstract}

Themionic energy conversion (TEC) and metallic-fluid heat pipes (MFHPs) offer import ant and unique advantages in terrestrial and space energy processing. And they are well suited to serve together synergistically. TEC and MFHPS operate through working-fluid vaporization, condensation cycles that accept great thermal power densities at high temperatures. TEC and MFHPs have apparently simple, isolated performance mechanisms that are somewhat similar. And they also have obviously difficult, complected material problems that again are somewhat similar. Intens ive investigation reveals that aspects of their operating cycles and material problems tend to merge: "In short, high-temperature material effects determine the level and lifetime of ... performance." Simplified equations verify the preceding statement for TEC and MFHPs. Material properties and interactions exert primary influences on operational effectiveness. And themophysicochemical stabilities dictate operating temperatures which regulate the thermoemissive currents of TEC and the vaporization flow rates of MFHPs. Major high-temperature material problems of TEC and MFHPs have been solved. These solutions lead to productive, cost-effective applications of current TEC and MFHPS -- and point to significant improvements with anticipated technological gains.

\section{Energy Efficacy and High-Temperature Materials}

"If there is a single general trend that applies to the various combinations of heat sources and conversion methods, it is the one toward higher source temperature and higher sink temperature -- and consequent ly lighter werght systems. For this reason, the workshop felt that high-temperature-materials data was of prome importance ...." This is a quotation from W. A. Ranken of the Los Alamos Scientific Laboratory, one of 150 experts who attended a recent symposium at NASA Lew]s Research Center on "Future Orbital Power System Technology Requirements" 1 . The inexorable evolution toward high space-system power levels is a movement to not only high temperatures but also high efficiencies and high power densities.

Similarly high-temperature, high-power-density topping promises higher efficiency, lower cost and less pollution per watt of electricity on earth 2-20. And very important in these trends are two direct energy devices that process great power densities effectively through hightemperature material interactions alone: The thermionic energy converter and the heat pipe operate on thermal inputs only and have no moving parts. Their workiny fluids cycle continuously through evaporation, condensation and return flow by a self-induced voltage or a caplllary-pressure difference ( $\left.F_{1 g} .1\right)$. Specially selected materials

*Work funded by the U.S. Department of Energy under Interagency Agreement EC-77-A-31-1062. serve as interacting evaporators and condensers as well as containers for these working flulds. In such combinations thermionic-energy-conversion (TEC) and heat-pipe processes function at low temperatures. But the or high-power-density capabi11ties prevall at high temperatures ( $F$ igs. 2 and 3). "In short, high-temperature material effects determine the level and iffetime of ...performance" 21 .

Temperatures for optimum TEC and for some important terrestrial topping applications appear in Fig. 2. Corresponding heat-pipe utilization could occur at temperatures near those for appropriate emitters and coliectors. Possible heat-pipe service in projected space applications comprises the entries in Table 1, $1,22-25$. Metallic fluid heat pipes (MFHPS) and TEC are also a synergistic combination for efficient high-temperature, highpower-density production of weight-effective space power near and above the megawatt leve 126,27 . Alming at that goal the USSR reported in 1976 on "the tests of three 'Topaz' reactors" ("thermionic nuclear power plants") that" demonstrated ... long-term stable and reliable operation with good reproducibility of parameters" 28 .

\section{TEC and MFHP Power Densities and Problems}

TEC heat inputs can reach the order of $100 \mathrm{~W}_{\mathrm{t}} / \mathrm{cm}^{2}$, as implied by $\mathrm{F} \mathrm{ig} .2$. There TEC outputs range up to tens of $W_{e} / \mathrm{cm}^{2}\left(P_{O L}\right)$ and tens of percent efficiency (nOL):

$$
\begin{aligned}
& P_{O L}=\left(\phi_{E}-\phi_{C}-v_{D}-v_{A}-V_{L}\right)\left(J_{E S}-J_{R}\right) \\
& n_{O L}=\left(J_{E S}-J_{B E}\right)\left\{\phi_{E}-\phi_{C}-v_{D}-v_{A}-2\right. \\
& {\left.\left[2.45 \times 10^{-8} n_{E C}\left(T_{E}^{2}-T_{C}^{2}\right) /\left(2-\eta_{E C}\right)\right]^{1 / 2}\right\} / } \\
&\left\{J_{E S}\left(\phi_{E}+2 k T_{E}\right)-J_{B E}\left(\phi_{E}+2 k T_{C}\right)+5.7 \times 10^{-12}\right. \\
& {\left.\left[0.05+7.5 \times 10^{-5}\left(T_{E}-1000\right)\right]\left(T_{E}^{4}-T_{C}^{4}\right)\right\} }
\end{aligned}
$$

In these equations $\phi_{E}$ and $\phi_{C}$ are emitter and collector work functions, $V_{D}$ is the interelectrode voltage drop, $V_{A}$ is the equivalent auxiliary input voltage for enhancement, $V_{L}$ is the voltage loss required for optimum leads (equal to the expression within the square brackets in the numerator of (2)), IEC is the TEC electrode efficiency (equal to (2) with $2 V_{L}$ deleted from the numerator), $T_{E}$ and $T_{C}$ are emitter and collector temperatures, the last term in the denominator of (2) approximates nonelectronic thermal transport, $J_{R}$ is reverse electronic flow (including reflections, backscattering, back emission $J_{B E}$, and other effects that diminish output current), and JES is the current density 
for emitter saturation:

$$
J_{E S}=A\left(1-R_{E}\right) T_{E}^{L} \exp \left(-\phi_{E} / k T_{E}\right)
$$

where $A$ and $k$ are Richardson and Boltzmann constants and $R_{E}$ is the emitter reflection coefficient.

Equation (2) is a simplified, yet reasonable est imate applicable for low cesium concentrations, reduced enhanced-mode pressures, close electrode spacings, and small interelectrode losses. Under such conditions the back emission $\left(J_{\mathrm{BE}}\right)$ approximates $21,26,29-31$

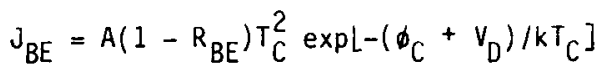

where $R_{B E}$ comprises $R_{C}$ (collector reflection coefficient) and similar coefficients for all interelectrode mechanisms that return collectoremitted electrons to their source -- except those for noncollisional repulsion by the emitter sheath. With negligible interelectrode losses and reflections, back emission equals that for collector saturation:

$$
J_{C S}=A\left(1-R_{C}\right) T_{C}^{2} \exp \left(-\phi_{C} / k T_{C}\right)
$$

The preceding equations verify a previous assertion: $\mathrm{H}_{\mathrm{gh}}$-temperature material effects $\left(\phi_{E}, R_{E}, T_{E}, J_{E S}, \phi_{C}, R_{C}, T_{C}, J_{C S} \ldots\right.$ ) determine the level of TEC performance -- completely. Thrs generalization inciudes enhanced-mode operation aiso because $V_{A}$ represents a small fraction of TEC output recycled to increase efficiency. With this rather i imited background a tabulation of TEC characteristics may now be apropos:

\section{Thermionic-Energy-Conversion (TEC) Advantages}

Electricity directly from heat

No moving parts or inherent mechanical stresses

High temperatures: high Carnot efficiencies

Great power densities - with

Broad near-maximum-efficiency plateaus

Rapid responses to load or heat variations

(constant temperature)

Low werghts

Small volumes

Modularity

Modularity In TEC Applied Research and Technology (ART)

TEC ART is essentrally independent of other system components

Development and testing on the lab bench are effective

Converters are scalable

Module bullding blocks adapt to system size and shape

Repetitious rotational fabrication modes apply

Nearest-neighbor load sharing minimizes unitfallure effects

Modular designs allow TEC-unit replacements

Economy: research, development, fabrication, application

Adaptability

Reliability

Maintainability
Although TEC accepts great thermal power densities, MFHPs excel in this capability: They can receive and deliver thousands of $w_{t} / \mathrm{cm}^{2} \mathrm{radi-}$ a liy and tens of thousands axially. Such performance falls within an envelope of mechanistic limitations typified by the following sketch.

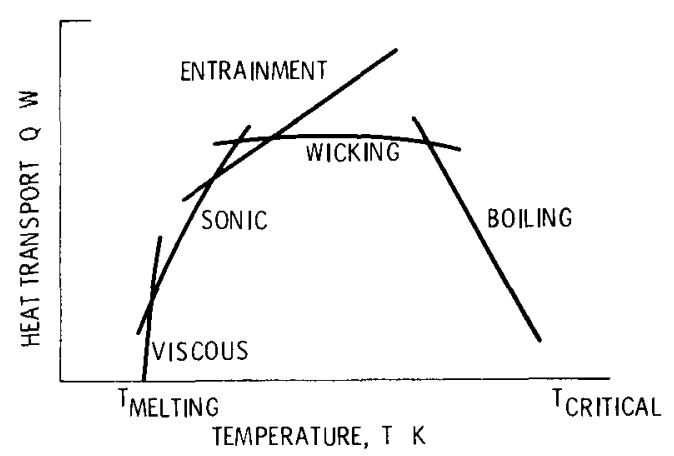

HEAT PIPE PERFORMANCE LIMITS

A simplified, yet informative expression for maximum heat-p ipe thermal power $Q_{\max }$ results from reduction of a complicated quadratic equation by neglecting inertial and interphase effects $32-34$ :

$$
Q_{\max }=\left(\frac{2 A_{w}{ }_{w}}{r_{p} L}\right)\left(\frac{\sigma_{1} \rho_{1} \lambda_{1}}{{ }_{1} 1}\right)\left(1-\frac{\rho_{1} g L r_{p} \sin \psi}{2 \sigma_{1}}\right)
$$

In this equation the first factor is the "wick number" $\left(N_{W}\right)$, the second, the "liquid-transport factor" or "zero-g figure of merıt" $\left(\mathrm{N}_{1}\right)$; and $2 \sigma / g \rho l$ is the "one-g wicking height" $\left(N_{p}\right)$. The subscripts $w, 1$, and $p$ designate "wick,"

"7 rquid" and "pore." And A is area; g, gravity vector; $K$, permeability; $L$, length; $r$, radius; $\psi$, inclination angle from horizontal; $\lambda$, heat of vaporization; $\mu$, viscosity; $\rho$, density; and $\sigma$, surface tension.

Equation (6) verifies that, aside from internal geometry, high-temperature-material properties $\left(\lambda_{1}, \mu_{l}, \rho_{1}\right.$ and $\left.\sigma_{1}\right)$ and the ir effects determine the level of MFHP perfomance. Perhaps this context makes the general characteristics of heat pipes more meaningful:

\section{The Heat Pipe}

Is a thermal-energy transporter, transformer, and isothermalizer;

Is a compact, lightweight, self-contained, selfpumped system;

Operates with no mechanical or electrical inputs and no moving parts,

Allows diverse temperature ranges, high thermalpower densities, and low temperature gradients:

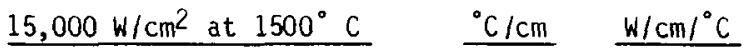

Lithrum ( $\left.L_{1}\right)$ heat $p i p e \quad 0.1 \quad 150,000$

$\begin{array}{lrr}\text { Molten copper }(\mathrm{Cu}) & 4000 & 3.75\end{array}$

The preceding simplified a lgebraic expressions indeed indicate that properties and interactions of materials at nigh temperatures dictate TEC and MFHP performances at the ir maxima. But an introductory quotation states that "hıgh-temperature 
material effects determine the level and lifetime of ... perfomance." And because thermally exponential tendencies of degradation-rate constants can be crucial, the fact that "high-temperature material effects determine the ... infetime" is of ten more important. In practice, thermophysicochemical stability 17 mits operating temperatures, hence TEC thermal emission and MFHP vaporization rates. Therefore, can highperformance TEC and MFHPS withstand thermally accelerated deterioration and live productively to economically old ages?

Answering this question requires first a diagnosis of some of the more destructive ravages possible during high-temperature TEC and MFHP operation: Both devices are subject to internal alkalımetal corrosion and solution accelerated by low concentrations of impurities like oxygen. In terrestrial service both must survive external attacks by hot corrosive gases. For space applications both must oppose sublimation of the ir exterlor surfaces into the hard-vacuum ambiance. And the near-vacuum within TEC admits of vaporization, condensation complications that could cause workfunction alterations and coat insulators. Also wherever interfaces of differing materials encounter high temperatures, reaction and diffusion loom as major concerns. Accentuated effects of the latter phenomenon occur when composition discontinuities promote void formations (Kirkendall) that diminish transport cross sections. Finally thermal creep, expansion coefficient mismatches, and solid-phase transitions demand attention in temperature cycling and gradients.

But as subsequent discussion reveals, solutions for these problems are avallable to make high-temperature TEC and MFHPS viable.

\section{Successful Limitation of Alka7i-Metal Corrosion}

Since the 1960's TEC technologists have considered cesium (Cs) corrosion under control to the extent that it no longer poses problems. As reference 35 states "... the materials used are not attacked by $C s . . . "$ In addition, ut 11 ization of ultra-pure Cs, strict cleanliness, effective getters and high-temperature vacuum bake-outs insure long lifetimes for TEC interiors.

The same general approach produces acceptable results for MFHPs, where $L_{1}$ usually provides the ultimate corrosion test. But in 1973, reference 36 asserted, "It has been concluded that $W-26 R e / L$ $(S, C)$ heat pipes promise a lifetime of many years at $1600^{\circ} \mathrm{C} . "$

This achievement is particulariy noteworthy because the heat-p ppe cycle concentrates corrosion-accelerating impurities at the evaporator surface. Therefore localized themochemical attack intensifies continuously in the performance-affecting f 1 ne structure of the wick as indicated in Fig. ${ }_{4} 37$.

Such alkali-metal-corrosion effects catalyzed by oxygen (0) dramatize the importance of oxide getters as metallic-fluid preloading processors, as in situ purifiers and as alloy constituents. of course good getters release much enthalpy and undergo nearly as great negative free-energy changes upon combining with 0 -- like the metals in lower Fig. 538-41. A qualitative version of some of these data simplifies their presentation somewhat in Fig. 642. A great difference between free energies of ox lae formation for two metals indicates a strong 0-gettering proclivity for the one with the more-negative free-energy change. But this is a generalization based on equilibrium concepts. And degrees or rates of approach to equilibria are not estimable from free-energy values. In fact solid-state transport usually controls gettering rates after initial superficial reactions.

However Figs. 5 and 6 provide some interesting TEC and MFHP insights: One is the observation that TEC Cs can scavenge impurity oxygen, then surrender it to the $\mathrm{Ta}$ or $\mathrm{ND}$ envelopes. This clean-up process might have caused early relatively uncontrolled TEC tests, which of ten began with high performances typical of 0 -additive enhancement, to taper off to lower efficiencies with continued operation.

Consensus places $\mathrm{O}$ solubility in Ta and $\mathrm{Nb}$ near one percent at several hundred degrees cent 1grade and greater than five percent above $\sim 1500^{\circ}$ C $43^{-46}$. But dissolved oxygen embrittles these refractory metals. So popular $\mathrm{Ta}$ and $\mathrm{Nb}$ alloys incorporate small amounts of hafnium ( $\mathrm{Hf}$ ) and zirconium $(Z r)$, respectively, to getter solidsolution 0, fix it as distributed oxides, and reduce brittleness 47 . But welding and other hot processing tend to segregate slag and other $1 \mathrm{~m}-$ purities at interfaces. Thus, because $L i$ can attack Ta, Nb, Zr, and Hf oxides successfully, $L$, heat pipes of such alloys of ten succumb to intergranular and weld perforations. However, as previously stated, properly processed $W$ alloys serve admirably as $n$ igh-temperature $L i$ heat pipes. This statement is also true for Mo and some Mo alloys.

Although $L 1$ can getter 0 from most oxides, it is subject to gettering by a few metals like those at the bottom of Fig. 5. One of these, lanthanum (La), is present in the order of a tenth percent in Haynes Alloy 188 (cobalt (Co) $\sim 40$ percent, nickel $\left(\mathrm{N}_{1}\right) \sim 22$ percent, chromium $(\mathrm{Cr}) \sim 22$ percent, tungsten ( $W$ ) $\sim 14$ percent and iron ( $F e$ ) -2 percent). It is noteworthy that a Haynes 188 , 11 thium heat pipe has been and 15 running with an evaporator temperature of $\sim 1250 \mathrm{~K}$ for over 19,000 hours (mid-November 1980) at the NASA Lew1s Research Center. This heat pipe was part of a project to determine advantages of very hightemperature, hard-vacuum preloading bake-outs on $L i$ and sodium $(\mathrm{Na})$ compatibilities with several superalloys during heat-pipe operation. In practically all such preceding compatibility studies, access to corrosion-accelerating impurities had been assured. Unfortunately the project objective was thwarted at the outset because the supplier was forced to use metal-felt wicks, which are difficult to clean up, rather than the stipulated screen. As a result, bake-out achieveo only in the order of $10^{-4}$ torr rather than the specified lower than $10^{-7}$ torr. Subsequently the other (non-HA188) superalloy, $L_{1}$ heat pipes falled early with destroyed wicks and severe internal wall attacks. Two Haynes 188 , L 7 heat pipes developed leaks in stress cracks caused by welding after $\sim 200$ hours. But sectioning and microscopic examination revealed no $L 1$ effects on wicks or walls (unpublished results from W. B. Kaufman, W. E. Frey and J. F. Morris of NASA Lew s Research Center). 
In this vein $T$ i-alloy, $L$ i heat pipes should also be avarlable soon for long-l ived, werghteffective space applications ranging to over $1300 \mathrm{k}^{37}$. Such availability was unexpected for years because some authoritative heat-pipe publications state that the only alkali metal compatible with $T 115 \mathrm{Cs}$. But a preponderance of non-heat-pipe 11 terature indicates that $T_{1}$ should serve well with any alkali metals as working fluids, including $L_{7}{ }^{37}$. Contract verification of this assertion is underway.

Such additional success in limiting alkalimetal corrosion will enhance TEC as we 11 as MFHP techno $\log 1$ es.

\section{Protection Against External Hot Corrosive Gases}

Advantageous terrestrial utilization of TEC and MFHPs demands operation with direct exposure to fossil-fuel combustion products at high temperatures. And such service requires efficacious protective coatings on heat-receiving surfaces. But subjection to high velocities and mechanical stresses is unnecessary because MFHPs can collect low thermal-power densities and transform them to appropriate, nearly isothermal TEC inputs.

Silicon-Carbide (SIC) clads for TEC in topping of power plants (TOPP) arose as a promising solution to this hot-corrosion problem $2,14-18,48-54$ during pre-1970 Office of Coal Research contract studies. Reference 2 reports on the thermal-shock stability, thermal-expansion compatibility, molten-slag resistance and hot-corrosion protection of SiC-clad TEC. Recent EPRI-supported work on coal-fired recuperators and regenerators further supports SIC as a high-temperature heatreceiving surface.

Now Thermo Electron Corporation (TECO) is testing a series of SiC-clad TEC drodes in fossil-fuel combustion products. One with a $1730 \mathrm{~K} \mathrm{~W}$ emitter passed 3500 hours (early December 1980) and 15 continuing. Tests after over 5000 hours for another SiC-clad converter with a $1630 \mathrm{~K} \mathrm{~W}$ emitter yielded gratifying results 54 .

"Electron microprobe analysis showed no evidence of any reaction between the interfaces of the tungsten, graphite, and silicon carbide. X-ray diffraction patterns of the silicon carbide were compared to those from unfired silicon carbide. The patterns were essentialiy identical and showed primarily silicon carbide. Knoop microhardness tests ind icated there was no change in the hardness during the life test. The hardness at the dome was KHN 2600. The following impurities were found on the dome area of the hot she11: aluminum, magnesium, potassium, and iron. The first three probably originated from the furnace firebrick and the iron from the melted flue pipe. Significantly, no chemical reactions between these elements and the silicon carbide were indicated. Apparent ly, no change or degradation to the composite shell resulted from the 5000 hours of operation."

TECO also revealed that TEC fabrication based on chemical vapor deposition (CVD) with suitable
SiC cladding is more economical than conventional fabrication for lower-temperature superalloy protection. The laminar $W$, graphite (C), SiC dome (emitter, thermal-expansion adapter, protective coating) can also be manufactured on reusable mandrels. So directly-fired TEC appears costeffective as well as feasible.

TECO has also demonstrated adaptability of their methods to produce SIC-Clad MFHP envelopes.

\section{Loping with External and Internal Vaporization}

Some lower-temperature terrestrial applications of TEC and MFHPs anticipate external notcorrosion protection by superalloys as previously mentioned. Such materials of ten serve well considerably hotter than $1400 \mathrm{~K}$ in combustion products because of adherent protective-oxide formations (see numerous NASA LeRC publications on superalloys ${ }^{55}$ ). Therefore it is not 17 logical to assume that the absence of corrosive attack in the chemically benign hard vacuum of space should allow satisfactory service by these superalloys at even higher temperatures. But of course this assumption fails to eventuate.

As Fig. 7 testifies the most important supera) loy constituents ( $\mathrm{Co}, \mathrm{Cr}, \mathrm{Fe}$ and $\mathrm{N}_{1}$ ) vaporize separately at about a mil per year between 1150 and $-1250 \mathrm{~K}$. Of course escape rates from alloys differ from those of pure materials because of dilution, association, and diffusion effects. But Fig. 7 enables estrmates of high-temperature vaporization into vacuum for non-associated surface components. And a mil per year is significant for lightweight space structures.

Much slower vaporization rates as well as higher melting points, great strengths and much lower densities make $T_{i}$ alloys excellent cand $1-$ dates for MFHPs in space 37 (Fig. 8). Ti sub1 imes at only $0.1 \mathrm{~m} 1 \mathrm{l} /$ year near $1300 \mathrm{~K}$. But such service temperatures for unprotected $\mathrm{T}_{1}$ envelopes on earth would be inconceivable. Here long-term use of unclad $T_{1}$ generally occurs at temperatures below $870 \mathrm{~K}$.

For satisfactory sublimation rates at temperatures above $1300 \mathrm{~K}$, alloys of Mo and $\mathrm{W}$ or even of $\mathrm{Nb}$ and $\mathrm{Ta}$, with proper precautions, Can serve we 11 for TEC and MFHPs (Fig. 7) -- bare for space and other vacuum environs and suitably clad for usual terrestrial applications.

As previously described, MFHPs function through evaporation, condensation, wick ing cycles for fluid metals: Internal pressures tend to center around one atmosphere, of ten between 0.1 and 10 atmospheres. But although metal vaporization prevalls in MFHPs, wick and envelope materials must be thermally stable to maintain geometries essential to performance.

However vaporization, deposition problems demand special attention in TEC, where high temperatures and surface phenomena dictate performance. Line-of-sight or maze shielding can preclude insulator short-outs. But emitter-vapor deposition can be critical on the collector. Adsorption of only a fraction of an atomic layer, less than $10^{-7} \mathrm{~cm}$, of a different material on an electrode can drastically alter its work function and electron reflectivity -- hence its TEC per- 
formance (Eqs. (1) to (5)). Thus emitter-vapor deposits on the collector are as important as they are unavoidable $e^{56}$ :

"The hot, close-up emitter practically covers the several-hundred-degrees-cooler collector. And the emitter vapor pressure is several orders of magnitude higher than that of an emitter-vapor deposit on the collector. So in low-pressure converters the arrival rate of emitter vapor on the collector is several orders of magnitude greater than the departure rate of its accumulated emitter-vapor deposit. This arrival-to-departure ratio approximates the actual emitter vapor pressure divided by its vapor pressure at the collector temperature with that quotient multiplied by the square root of the collector-to-emitter temperature ratio."

Accordingly in TEC, emitter-vapor deposits tend to build up on collectors. Therefore utilizing the material deposited on it by the emitter as the collector is a simple, general solution for this TEC vaporization, deposition problem. 0ther answers are possible but exceptiona]18,21.

In any event coping with internal and external vaporization in TEC and MFHPs essentially reduces to selection of the proper materials, which are avallable and viable.

\section{Controlling Interfacial Reactions and Diffusion}

Aside from the previously discussed workingfluid influences, reaction and diffusion effects are really not problematic in standard MFHPs. Selection, electron-beam welding and hightemperature, hard-vacuum baking of identical wick and envelope materials, which have proven thermophysicochemical stability, practically eliminate such problems to over $1600^{\circ} \mathrm{C}$. And external hotcorrosion protection developed for TEC applies at least for small and intermediate heat pipes, which offer the advantage of near-isothermality.

In high-temperature fossil-fuel combustion products, the TECO SiC, $C$, W dome for TEC showed "no change or degradation ... from 5000 hours of operation" with a $1630 \mathrm{~K}$ emitter. In vacuum, a cylindric diode with a $1973 \mathrm{~K} \mathrm{~W}$ emitter $0.23 \mathrm{~mm}$ from a $\sim 1073 \mathrm{~K} \mathrm{Nb}$ collector generated $8 \mathrm{~W} / \mathrm{cm}^{2}$ at $0.76 \mathrm{~V}$ and 14 percent electrode efficiency for over 5 years before a 1973 contract termination stopped it. So interfacial reactions and diffusion appear well under control in standard TEC also.

Introduction of new high-performance electrodes sometimes causes difficulties. For example NASA LeRC proposed a $C S$ diode with an emitter and a collector of $\mathrm{La}$ hexaboride $\left(\mathrm{LaB}_{6}\right)$ in the late $1960^{\prime} \mathrm{s}$ and again during the reactivation of its TEC program in 197457. In 1977 NASA LeRC and USSR technologists both demonstrated highperformance TEC with nonoriented $L_{a B} 6$ electrodes $58-60$. Controlled deposition of polycrystalline metal-hexaboride films 61 , with preferred or etch-relieved 100 or 210 orientations for $\mathrm{LaB}_{6} 62-67$, promise even better performance in practical TEC conf igurations (s imilar to CVD'd 110-W electrodes in cylindric drodes). And gratifyingly the published consensus in 1974 indicated that brazing, diffusion and reactions between $\mathrm{LaB}_{6}$ and its support were not problems. But today the inability to maintain a $1700 \mathrm{~K} \mathrm{LaB}_{6}$ emitter on a refractory-metal base for over 100 to 200 hours 68,69 st 171 frustrates practical applications. However history teaches that such diffusion and reaction problems usually yield to concentrated applied research.

In general the problem of "contact diffusion interaction of materials" causes major difficulties originating at high-temperature interfaces 70,11 . Other pertinent examples are the previously mentioned solution effects of alkali metals and oxygen (particularly in niobium and tantalum) as well as the intermingling of fuel with its immediate container in nuclear power generators like the in-core thermionic-converter or heat-pipe configurations.

In the latter area reference 70 presents results obtained by a group of USSR Scientists who contributed theoreticaliy and experimentally to the understanding of fuel, clad interactions. In turn reference 71 corrects the ir simple diffusion equation, then derives more rigorous versions through Laplace transformation of the differential rate expression, "small-system" approximation, and finaliy complete inversion with subsequent simplification:

$C(x, t) \approx C(0,0)\left[1+\cos \left(\frac{k x}{D}\right)-\cos \left(\frac{k^{2} t}{D}\right)\right] \exp \left(-\frac{k^{2} t}{D}\right)$

where $C$ is concentration of $A$ in $B$ varying over a short time $t$ and very small distance $x$ in accordance with a dominating diffusion coeff $1-$ cient $D$ for $A$ in $B$ and a layer-growth constant $k$.

Diffusion is of course a critical influence as an entity at high-temperature interfaces. But more crucially it generaliy dictates rates of corrosion and other chemical reactions in practical systems -- after the initial superficial interactions deplete local compositions. To further elucidate the last observation, consider the simplistic but heuristic example of pure-metal oxidation controlled by migration in an ideal solution (after Evans 72 , from Hurlen 73 ). For this situation the absolute reacton-rate theory (Eyring, Laidler and Glasstone) yields an expression for one-dimensional net transport of a species (corrected from Ref. 72):

$$
\begin{aligned}
V= & (\lambda k T / h) \exp \left(-\Delta G_{0}^{\ddagger} / R T\right)[c \exp (-\alpha \lambda z F d \phi / R T d x) \\
& -(c+\lambda d c / d x) \exp ((1-\alpha) \lambda z F d \phi / R T d x)]
\end{aligned}
$$

The pre-bracket factor, specific rate for a unit concentration without fields, involves no net transport. The first term in the bracketed factor represents acceleration by the field. The second term in the brackets covers retardation. Also in (8) $v$ is the net transport rate; $\lambda$, the equilibrium distance between migrating charged particles; $k$, Boltzmann constant; $T$, degrees Kelvin; $h$, Planck constant; $\Delta G F$, standard chemical activation energy; $R$, gas constant; $c$, concentration of $\mathrm{m}_{1-}$ 
grating species; $\alpha$, symmetry factor; $z$, migratingparticle charge; $F$, Faraday equivalent; $\phi$, inner potential; and $x$, distance in the transport direction.

Simplifying assumptions and transformations lead to an approximate expression for film thickness $y$ related to an equivalent oxide volume $V$ and to $\Delta$ values across the film:

$$
\begin{aligned}
\mathrm{dy} / \mathrm{dt} & =V v(y), \Delta \phi / y=d \phi / d x, \\
\Delta c / y=d c / d x, \Delta G=F / \Delta \phi \text { and } \alpha=1 / 2 & \\
\mathrm{dy} / \mathrm{dt} & =\sum_{1} \pm k_{1} c_{1, y}\left[\exp \left(-\lambda_{1} z_{1} \Delta G / 2 R T y\right)\right. \\
& \left.-\left(1+\lambda_{1} \Delta c_{1} / y c_{1, y}\right) \exp \left(\lambda_{1} z_{1} \Delta G / 2 R T y\right)\right]
\end{aligned}
$$

where $t$ is time and $K=(V \lambda k T / h) \exp \left(-\Delta G_{0}^{\ddagger} / R T\right)$. From this simplified yet unwieldy equation Evans extracts some of the more common reduced forms used to correlate corrosion data.

For high temperatures and large film thicknesses the exponential of Eq. (10) submits to series expansion with small-term elimination:

$$
\begin{aligned}
\mathrm{dy} / \mathrm{dt} & \approx\left[\sum_{1} \mp \mathrm{K}_{1} \lambda_{1} c_{1}, y\left(z_{1} \Delta G / R T+\Delta c_{1} / c_{1}, y\right)\right] / y \\
& \Rightarrow\left(\sum_{1} \mp k_{1} \lambda_{1} \Delta c_{1}\right) / y \text { or } y^{2} \approx k_{p} t+\text { const. }
\end{aligned}
$$

And the classic parabolic corrosion expression results.

In contrast for low temperatures and small film thicknesses a bracketed exponentidl term in Eq. (10) approaches negligibility:

$$
\begin{aligned}
& \mathrm{dy} / \mathrm{dt} \approx \sum_{1} \mathrm{~K}_{1} c_{1, y} \exp \left(\mp_{\lambda_{1}} z_{1} \Delta \mathrm{G} / 2 \mathrm{RTy}\right) \\
& \text { or } y^{-1} \approx \text { const. }-K_{\text {IL }} \log t
\end{aligned}
$$

This is the inverse-logarithmic relationship for corrosion.

A cubic version derives from corrosion modeis invoking assumptions of semiconductor properties for the oxide $f 11 \mathrm{~m}$. The result is equivalent to assuming corrosion conditions validating ap 2 as an approximation of $\exp (p)-\exp (-p)$ in Eq. $(10)$ :

$$
\begin{array}{r}
d y / d t \approx a\left[\sum_{1} K_{1} C_{1, y}\left(\lambda_{1} z_{1} \Delta G / 2 R T\right)^{2}\right] / y^{2} \\
\text { or } y^{3} \approx K_{c} t+\text { const. }
\end{array}
$$

Rather than semiconduction, catalysis assumed in corrosion modeling can lead to linear time dependency. And all these variations evolve from an admittediy simplistic, even unattainable system of a pure metal limited in corrosion by transport through an ideal solution. Complications of alloys, nonideal multicomponent solutions, steep temperature gradients, inhomogenieties and myriad other realities are normal effects in actual interfacial diffusion and reactions. But this somewhat superficial description begins to indicate the problems and underscores the importance of life testing.

The preceding amplification began with a comment on new high-performance TEC electrodes $17 \mathrm{ke}$ $\mathrm{LaB}_{6}$. Gratifyingly, unoriented and CVD'd 110-W electrodes with negligible interelectrode losses can provide optimal TEC for applications requiring $\sim 1000$ - to $\sim 1100 \mathrm{~K}$ collectors 18 . Furthermore high performance $W$ and Mo electrodes with stable or steady-state supplies of enhancing 0 are in the offing 74 . And for such TEC materials "interfacial reactions and diffusion appear well under control."

\section{Meeting Other Thermophysical Challenges: Expansion Matches, Creep...}

One of the first considerations in anticipation of a laminar composite, particularly of unforgiving refractory materials like tungsten and silicon carbide, is the match of themal-expansion coefficients. An excellent example of such an evaluation from the late $1960^{\prime} s$ appears in Ref. 2: Fig. 9(a) comprises prepublished data75; Fig. 9(b), data obtained during the pub11shed study 76 . Separately the sets of results reveal near-matches for $W$ and SiC thermal expansions. Together they predict practical coincidence.

The significance of this comparison was impressive in the late $1960^{\prime} \mathrm{s}$, even as it is today 77 :

"Six molybdenum tube samples, coated with various thicknesses of thick grain CVD silicon carbide have been received from Chemetal and subjected to a serres of thermal shock tests, both in a vacuum furnace and in a natural gas flame. The objective was the evaluation of the coating adhesion. Temperature cyciong in the vacuum furnace covered the range from approximately 400 to $1500 \mathrm{~K}$. The samples were inspected after one, three, and $51 x$ temperature cycles. Following these tests, the surviving samples were subjected to natural gas flame heating and ambient air cooling for a total of approximately 40 cycles. The conclusion reached in these preliminary tests is that when a thin intermediate layer of tungsten is used, the molybdenum substrate-CVD silicon carbide coating w111 withstand the thermal stresses over the temperature range of interest. No evidence of layer separation was disclosed in metallographic examination of tube samples."

The contribution of this thermal-expansion-match observation is critically important to MFHPs for terrestrial use as well as to TEC.

Incidentaliy, a reference-2 silicon carbide sample "temperature cycled over 7300 times" in. hydrocarbon-combustion products "to about $2800^{\circ} \mathrm{F}$ in about one minute," followed by "a two-minute 
cool-off to about $700^{\circ} \mathrm{F}$. Coal ash was deposited on the surface of the test sample during the cooldown portion of the test cycle... The only visible effect on the silicon carbide was an erosion of about 0.02 inch where the" pressurized flame impinged on the sample. "It was apparent that the temperature of this point was considerably higher than the measured temperature of the test sample .... As before, solidified coal ash was evident on the tube surface, but sectioning and metallographic examination... showed no coal ash penetration of the silicon carbide. The solidified coal ash observed on the test sample was a result of the final cool-down. During the temperature cycling, good run-off of the coal ash was observed at the high temperatures, leading to the conclusion that the final air heater would indeed be self-cleaning."

Subsequent references on SIC service in fossil-fuel combustion products support and augment reference-2 findings $48-54,77$. For example, TECO recently heated its SIC, C, W dome at $1875^{\circ} \mathrm{K}$ for over 70 hours, sprayed water on it at $1875 \mathrm{~K}$ 10 times ( $1000 \mathrm{~K}$ between the water-cooled spot and the rest of the dome), poured liquid nitrogen on it at $1875 \mathrm{~K} 10 \mathrm{times}$, then cycled it from $1875 \mathrm{~K}$ to $<900 \mathrm{~K}$ over $150 \mathrm{t}$ imes, then from $2025 \mathrm{~K}$ to $<900 \mathrm{~K}$ over 100 times taking about one minute for each cycle -- all with no 111 effects to the SiC, $C$, W dome.

Interestingly, TECO uses $C$ to more carefully adapt silicon-carbide thermal-expansion to that of $W$. And Chemetal77 utilizes $W$ for thermalexpansion adaptation of SiC to Mo. The latter lamination has yet to undergo long-term hightemperature exposure to fossil-fuel combustion products, successfully experienced by the former. But results of both approaches are gratifying.

In addition to the thermal-expansion effects, refractory-material strength and creep at high temperatures are of course important in TEC and MFHP applications. In this vein, just subsequent to mentioning $S I C$ and $C$, two referential observations are pertinent: First "it is interesting to note that sintered $S_{1 C}$ exhibits an increase in strength with an increase in test temperature up to about $2800^{\circ} \mathrm{F} " . .78$. And second "graphite possesses high thermal conductivity, a low modulus of elasticity, a low coefficient of thermalexpansion, and relatively satisfactory strength increasing with increase in temperature to $2700^{\circ}$ C"79. Conceivably such protective clads and thermal-expansion adapters might also serve as structural members at high operating temperatures.

High temperature structural members are subject to the thermal creep $80-82$. This phenomenon is the time-depencent plastic deformation of a material under sustained loading at temperatures above about half its melting point value. Like many other thermophysical effects, creep is complex, even in pure polycrystalline metals. Here in general high-temperature creep resistance relates to high levels for the melting point, elastic modulus, stability of fine grain size, crystal-structure constant for self-diffusion, and valence state. Departing from pure metals introduces considerations of strengthening by solution, precipitation, dispersion and composite effects. In practical applications, permutations of complicating influences are myriad. For example, reference 47 states that "the maximum 0 level in $\mathrm{Na}$ necessary to avold embrittlement of $\mathrm{Nb}$ at $700^{\circ} \mathrm{C}$ has been estimated to be less than $10 \mathrm{ppm} . "$

The preceding scare tactics are really intended only to ind icate that published creep values for a given material can vary considerably with little or no apparent reason. But such information is particularly important for MFHPS and TEC in systems with $1800 \mathrm{~K}$ emitters. And for these applications, satisfactory materials are few as the creeg-strength curves of Fig. 10 17 lustrate 83 .

In any event high-tempurature TEC and MFHPS based on the creep resistance of $W$ and $W$ alloys have demonstrated in vacuum capabilities for many years of service. Ta, Nb and Mo alloys afford effective creep resistance for selected applications also. Figure 10 shows such alloys: T-111 (Ta, 8W, 2Hf), ASTAR-811C ( Ta, 8W, 1Re, 0.7Hf, $0.35 \mathrm{C})$, Nb, 1Zr, FS $85(\mathrm{Nb}, 28 \mathrm{Ta}, 10 \mathrm{~W}, 1 \mathrm{Zr})$, TZC (Mo, 1. LT T, 0.25Zr, 0.15C), and TZM (Mo, 0.5T 1, $0.08 \mathrm{Zr}, 0.03 \mathrm{C})$.

Weight-effectiveness in space and costeffectiveness in general drive towara minimal wall thicknesses alluded to in Fig. 8. For such conditions the previously mentioned "stability of fine grain size" is very important. This state not only maintains creep resistance, but also avoids recrystallization grain dimensions and intergranular paths approaching containment-wall thicknesses. The latter occurrence promotes flund leaks as well as strength discontinuities.

Specially selected additives can increase creep resistance, retard recrystaliızation and control solid-phase transitions of ten accompanied by abrupt changes in properties like thermal expansion. Referring again to titanium may exemplify the last observation 37 :

"Thermophysically, Ti undergoes a solidphase alteration at about $1160 \mathrm{~K}$. Here rising temperatures change the closely packed-hexagonal "alpha" structure to the body-centered-cubic "beta" configuration. However this transformation, like the $\alpha$-to- $\gamma$ transition for iron at $1180 \mathrm{~K}$, causes no great difficulties 84 . The $T_{1}$ $\alpha-t_{0-B}$ phase-change temperature rises with $A$ l additions and falls (even below room temperatures) with inclusions of Mo, $\mathrm{Fe}, \mathrm{Cr}$ or $\mathrm{V}$. Commercially avallable pure (99.6 percent) $T_{1}$ and $T_{1}, 5 A 1,2.55 n$ are alpha alloys. Tr, 8Mo, $8 \mathrm{~V}, 2 \mathrm{Fe}, 3 \mathrm{Al}$ is a beta alloy, and the most widely used $T r$, $6 \mathrm{Al}, 4 \mathrm{~V}$ is an "alpha-beta" alloy.

Like $T_{1}$, refractory metals $Z r$ and $H f$, aiso in periodic group IVA, undergo solid-phase transitions $43-46,84$. In contrast group $V A N b$ and $T a$ as well as group VIA Mo and Wexhibit no solidphase changes.

The considerations raised in this section represent some obvious difficulties that nave been overcome on the path to successful applications of high-temperature TEC and MFHPs. Many other lessimpressive thermophysical challenges have arisen, then fallen under the pressure of applied research. 


\section{High-Temperature TEC and MFHP's in Brief}

In addition to the detailed similarities of TEC and MFHPs emphasized in the introductory sections, a generalized parallel can be drawn: The two operating cycles appear as invitingly simple and isolated as their material problems seem forebodingly difficult and complected. The first observation is deceptive; the second, candid. Both areas required intense study and experimentation, which resulted in recognition of the ir singular relationship. "In short, high-temperature material effects determine the level and lifetime of ... perf ormance."

Simplified equations verify material properties and interactions as primary influences on the operational effectiveness of both TEC and MFHPs. And being essentially evaporation, condensation cycles, TEC and MFHPs experience flow limitations in thermal emission and vaporization because of temperature restrictions redounaing from thermophysicochemical-stability considerations. Thus attaining practical lifetimes generally implies limiting performances in exchange.

But as previous discussions reveal, major high-temperature material problems of TEC and MFHP have been solved. The solutions are workable and economical and lead directly to applications that are productive and cost-effective. In fact current performance and cost levels imply improved outputs, efficiencies, and economies for TEC topping of combustors, central-station power plants and other advanced conversion systems heated by high-temperature energy sources.

And ant Ic ipated technological gains point to even greater improvements for future TEC and MFHP applications by more fully utilizing high power densities from high-temperature material interactions.

\section{References}

1. "Future Orbital Power Systems Technology Requirements," NASA CP-2058, Sept. 1978.

2. Cassano, A. J., and Bedel1, J. R., "Thermionic Topping Converter for a Coal-Fired Power Plant," Consolidated Controls Corp., CCC-60-o 445-17, Bethel, Conn., 1970.

3. Huffman, F. N., Spelde l, T. O. P., and Davis, J. P., "Topping Cycle Applications of Thermionic Conversion," Record of the Tenth Intersociety Energy Conversion Engineering Conference IEEE, New York, 1975, pp. 490-502.

4. Britt,E. J., Fitzpatrick, G. 0., and Rasor, N. S., "Themionic Topping of Electric Power Plants," Record of the Tenth Intersociety Energy Conversion Conference, IEEE, New York, 1975, pp. 503-512.

5. Merri11, Owen S., and Cuttica, John J., "ERDA's Bicentennial Thermionic Research and Technology Program," Eleventh Intersociety Energy Conversion Engineering Conference, Proceedings, VoT. 2, American Institute of Chemical Engineers, New York, 1976, pp. 1635-1644.

6. Britt, E. J., and Fitzpatrick, G. 0., "Thermionic Topping for Central Station Power Plants," Eleventh Intersociety Energy Conversion Engineering Conference, Proceedings, Vol. 2, American Institute of Chemical Eng ineering, New York, 1976, pp. 1040-1045.
7. Miskolczy, G., and Speidel, T. O. P., "Thermionic Topping of a Steam Power Plant," Eleventh Intersociety Energy Cunversion Eng ineering Conference, Proceedings, Vo T. 2, American Institute of Chemical Engineers, New York, 1976, pp. 1050-1055.

8. Britt, E. J., and Fitzpatrick, G. O., "Increased Central Station Power Plant Efficiency with a Thermionic Topping System," Proceedings of the 12th Intersociety Energy Conversion Confer-

ence, Vol. 2, American Nuclear Society, La Grange Park, I11., 1977, pp. 1602-1609.

9. Miskolczy, G., and Huffman, F. N., "Evaluation of MHD-Thermionic-Steam Cycles," Proceedings of the 12th Intersociety Energy Conversion Conference, Vol. 2, American Nuclear Society, La Grange Park, I11., 1977, pp. 1610-1616.

10. Fitzpatrick, G. O., and Britt, E. J., "Thermionic Power Plant Design Point Selection: The Economic Impact," Proceedings of the 13th Intersociety Energy Conversion Engineering Conference, Vo 1. 3, Society of Automotive Eng ineers, Warrendale, Pa., 1978, pp. 1887-18yz.

11. Carnascialı, G., Fitzpatrick, G. 0., and Britt, E. J., "Performance and Cost Evaluation for a Thermionic Topping Power Plant," ASME Paper 77-WA/ENER-7, Nov. 1977.

12. Huffman, F. N., and Miskolczy, G.,

"Thermionic Energy Conversion Topp ing System," ASME Paper 77-WA/ENER-6, Nov. 1977.

13. Morris, J. F., "Comments on TEC Trends," Conference Record-Abstracts, International Conference on Plasma Science, Institute of Electrical and Electronics Engineers, Montrea 1, Canada, June 4-6, 1979, IEEE, New York, 1979, Abstract 6010, p. 166. Also NASA TM-79317, 1979.

14. Morris, J. F., "Potentrainties of TEC Topping: A Simplified View of Parametric Ef-

fects," IEEE Conference Record-Abstracts, International Conference on Plasma Science, University of Wiscons in, Madison, May 19-21, 1980, IEEE, New York, 1980, Abstract 1E8, p. 16. Also NASA TM-81468, 1980 .

15. Merril1, 0. S., "The Changing Emphasis of the DOE Thermionic Program," IEEE Conference Record-Abstracts, 1980 IEEE International Conference on Plasma Science, University of Wisconsin, Madison, May 19-21, 1980, IEEE, New York, 1980, p. I4.

16. Miskolczy, G., and Huffman, F. N., "Terrestrial Applications Using a Thermionic Array Module (TAM) Combustor," IEEE Conference RecordAbstracts, 1980 IEEE International Conference on Plasma Science, University of Wisconsin, Madison, May 19-21, 1980, IEEE, New York, 1980, pp. 15-16. 17. Dick, R. S., Britt, E. J., and

Fitzpatrick, G. 0., Electric Utility and Cogeneration Systems Appilications of Thermionic Energy Conversion," IEEE Conference Record-Abstracts, 1980 IEEE International Conference on Plasma Science, University of Wisconsin, Madison, May 19-21, 1980, IEEE, New York, 1980, p. 16. 18. Morris, J. F., "Optimal Themionic Energy Conversion with Established Electrodes for HighTemperature Topping and Process Heating," DOE /NASA / 1062-6, NASA TM-81555, July 1980.

19. Miskolczy, G., Wang, C. C., Margulies, A. E., and Fussgni, L. J., "Thermionic Topping of Combined Cycle Powerplants and Cogeneration Applications," Energy to the 21st Century, Proceedings of the 15th Intersociety Energy Conversion Engineering Conference, Seattle, Wash., Aug. 1980, Vol. 3, IEEE, New York, 1980, pp. 1783-1787. 
20. D1ck, R. S., Jr., Bunda, B. M., and Starr, J. W., "Design Study of a Coal-Fired Thermionic (THX) - Topped Power Plant, "Energy to the 21st Century, Proceedings of the 15th Intersociety Energy Conversion Eng ineering Conference, Seattle, Wasnington, Aug. 1980, Vo T. 3, IEEE, New York, 1980, pp. 1775-1782.

21. Morris, J. F., "The NASA ThermonicConversion (TEC-ART) Program," IEEE Transactions on Plasma Science, Vol. PS-6, No. 2, June 1978, pp. $180-190$.

22. "NASA Office of Aeronautics and Space Technology Summer Workshop," NASA TM X-73900, Aug 1975.

23. Sadın, S. R., "OAST Space Theme Workshop 1976," NASA TM X-3486, Apr. 1976.

24. "A Forecast of Space Technology, 1980-2000," NASA SP-387, Jan. 1976.

25. "Conference on Advanced Technology for Future Space Systems, Hampton, Va., May 8-10, 1979, Technical Papers," American Institute of Aeronautics and Astronautics, New York, 1979.

26. Morris, James F., "High-Temperature, HighPower-Density Thermionic Energy Conversion for Space," NASA TM X-73844, 1977.

27. Morris, James F., "Optımıze Out-of-Core Thermionic Energy Lonversion for Nuclear Electric Propulsion," IEEE International Conference on Plasma Science, Monterey, California May 15-18, 1978, IEEE, New York, 1978, Abstract IC6. AISO NASA TM-73892, 1978.

28. Kuznetsov, V. A., "The State and Directions of Thermionic Converters Research in the USSR," Eleventh Intersociety Energy Conversion Engineering Conference, Stateline, Nevada, September 12th to $17 \mathrm{th}, 1976$.

29. Hatsopoulos, G. N., and Huffman, F. N., "The Growth of Thermionic Energy Conversion," in Energy 10: Annual Intersociety Energy Conversion and Eng ineering Conference, IEEE, New York, 1975, pp. 342-350 (see Fig. 7).

30. Hatsopoutos, G. N., and

Gyftopoulos, E. P., "Thermionic Energy Conversion, Volume I: Processes and Devices, MIT Press, Cambridge, Mass., 1973.

31. Huffman, F. N., Sommer, A. H., Balestra, C. L., Briere, D. P., and

Oettinger, P. E., "High Efficiency Thermionic Converter Studies," Thermo Electron Corp., Wa] tham, Mass., TE 4202-12-77, Nov. 1976. (NASA CR-135125, 1976.)

32. De111, A. A. M., "Theory and Design of Conventional Heat Pipes for Space Applications," NLR TR-77001-U, National Aerospace Laboratory, The Netherlands, May 1977.

33. Chr, S. W., Heat Pipe Theory and Practice, McGraw-H1 11, New York, 1976

34. Dunn, P., and Reay, 0. A., Heat Pipes, Pergamon Press, New York, 1976.

35. Rouklove, P., "Metallurgical Study of Thermionic Converters," IEEE Transactions on Electron Devices, Vol. ED-16, No. 8, Aug. 1969, pp. 672-678.

36. Quataert, D., Busse, C. A., and Geiger, F., "Long Time Behavior of High Temperature Tungsten-Rhenıum Heat Pipes with Lithium or Silver as Working Fluid," International Heat Pipe Conference 1973, Preprints, October 15 to 17 , 1973, Stuttgart, Federal Republic of Germany, Institut fur Kernenergetik, Universitat Stuttgart, 1973, Paper 4-4.
37. Morris, J. F., "Titanium-Alloy, MetallicFlu1d Heat Pipes for Space Service," NASA

TM-79132, Mar. 1979.

38. Cook, R. H., and Skelton, R. P., "Environment-Dependence of the Mechanical Properties of Metals at High Temperatures, "Review 187, International Metallurgical Reviews, Vol. 19, 1974, pp. 199-222.

39. Huseby, I. E., and Klug, F. J., "Chemica? Compatability of Ceramics for Directionally Solidifying Ni-Base Eutectic Alloys," American Ceramic Soclety Bullet, $n$, Vol. 58, No. 5, 527 and $528,1979$.

40. Perry, R. H., Chrlton, C. H., and Kirkpatrıck, S. D., eds., Chemica] Engineers Handbook, 4th ed., McGraw-Hil1, New York, 1963.

41. Hatterer, A., "Obtentiondes Mataux Alcalins Purs," The Aikali Metals, Symposium at Nottingham, England, Juty 19 to 22, 1966, The Chemical Society, London, 1967, pp. 317-369. 42. Jaffee, R. I., and Maykuth, D. J. "Refractory Materiais," Battelle Memorial Institute Defense Metals Information Center, Columbus, 0., DMIC Memo-44, Feb. 26, 1960. (PB-161194.)

43. Hansen, M., Constitution of Binary Alloys,

2nd ed., McGraw-Hill, New Vork, 1958.

44. Elliott, R. P., Constitution of Binary Alloys, First Supplement, MCGraw-Hill, New York, 1965.

45. Shunk, F. A., Constitution of Binary Alloys, Second Supplement, McGraw-H1 17, New York, 1969.

46. Moffatt, W. G., Binary Phase Diagrams Handbook, General Electric Co., Schenectady, N. Y., 1978.

47. Mausteller, J. W., Tepper, F., and Rodgers, S. J., Alkal 1 Metal Handling and Systems Operatıng Techniques, Gordon and Breach, New York, 1967.

48. "DOE/JPL Advanced Thermionic Technology Program," Thermo Electron Corp., Wal tham, Mass., Progress Report No.'s 33 and Higher, 1978-1980.

49. "Development and Evaluation of Tubular $51 \mathrm{C}$ Recuperators," Heat Exchanger Technology Program News letter, Department of Energy, Office of Fossi 1 Energy Technology, May 1978, pp. 9-10.

50. Freche, John C., and Ault, G. Mervin, "Progress in Advanced High Temperature Turbine Materials, Coatıngs, and Technology," High Temperature Problems in Gas Turbine Eng ines, AGARD-CP-229, 1978, pp. 3-1 to 3-31.

51. "Coal-Fired Prototype High-Temperature Cont inuous-Flow Heat Exchanger, AF-684 Research Proj. 545-1," Electric Power Research Institute, Palo Alto, Calif., EPRI-AT-684, Feb. 1978.

52. Ternery, V. J., and We1, G. C., "Recuperator Materials Technology Assessment," Oak Ridge National Laboratory, ORNL/TM-6227, Feb. 1978. 53. Goodale, D. B., Lreb, D., Reagan, P., Miskolczy, G., and Huffman, F. N., "Characteristics of Flame-Heated Chemical Vapor deposited Thermionic Combustors," IEEE Conference RecordAbstracts, 1980 IEEE International Conference on Plasma Science, University of Wisconsin, Madison, May 19-21, 1980, IEEE, New York, 1980, p. 17. 54. Goodale, D. B., Reagan, P., Miskolczy, G., Lie, D., and Huffman, F. N., "Combustion Performance of CVD Silicon Carbide Thermionic Diodes," Energy to the 21st Century, Proceedings of the 15th Intersociety Energy Conversion Engineering Conference, Seattle, Washington, Aug. 1980 , Vo 1. 3, IEEE, New York, 1980, pp. 2095-2097. 
55. Weiss, V. and Sessler, J. G., eds., Aerospace Structural Metals Handbook, Vol. I IA, Syracuse University Press, Syracuse, N.Y., 1971.

56. Morris, J. F., and Lundholm, J. G., "NASA Thermionic-Conversion Program," Eleventh Intersociety Energy Conversion Eng ineering Conference, State Line, Nevada, September 12th to 17th, 1976, Proceedings, Vol. II, AICnE, New York, 1976, pp. 1652-1655. ATSO NASA TM X-73430, 1976.

57. Morris, J. F., "High-Efficiency, LowTemperature Cesium Diodes with LanthanumHexaboride Electrodes," NASA TM X-71549, 1974. See also IEEE 1974 International Conference on Plasma Science, Conference Record-Abstracts, IEEE, New York, 1974, Session 1A4, pp. 7-8.

58. Kroeger, E. W., Bair, V. L., and Morris, J. F., "Diminiode Thermionic Energy Conversion with Lanthanum-Hexaboride Electrodes," NASA TM-78887, 1978. Paper 1C8 presented at IEEE International Conference on Plasma Science, Monterey, Calıfornia, May 15-18, 1978.

59. Morris, J. F., "NASA, ERDA ThermionicConversion Tour of Europe and the USSR, 6/14 to 7/5/77, World Electrotechnical Conference, Moscow, $6 / 21$ to $6 / 25 / 77$ (a Chronological Trip Report),"

NASA Lewis Research Center, Cleveland, OH, 1977. 60 . Menabde, N. E., Tskhakaya, V. K., and Yaryg in, V. I., "Low-Temperature Thermionic Converter with a Lanthanum Hexaborlde Collector," Zhurnal Tekhnichesko1 Fizikı, Vol. 48,

pp. 770-772, Apr. 1978. (Soviet Physics-Technical Physics, vo1. 23, Apr. 1978, pp. 454-455.)

61. Huggens, R. A., Elwell, D.

Fergelson, R. S., and De Mattei, R. C., "(Long Range Materials Research) Development of ElevatedTemperature Electrocrystalization Techniques," Sanf ord Uaniversity, Calif., CMR-78-4, Feb. 1978.

62. Swanson, L.W., Dickinson, J. T., and McNeely, D. R., "Fabrication and Characterization of Composite Refractory Compounds Suitable for Thermionic Converters," NASA CR-2668, Mar. 1978.

63. Swanson, L. W., "Single Crystal Work Func-

tion and Evaporation Measurements of $\mathrm{LaB}_{6}$ and

CeB 6." IEEE Conf erence Record-Abstracts, the

1976 International Conference on Plasma Science,

Austin, Texas, May 24-26, 1976, IEEE, New York,

1976 , p. 142.

64. Davis, P. R., Chambers S. A., and

Swanson, L. W., "Adsorption of Cesium on Lanthanum

Hexaboride Surfaces," IEEE Conference Record-

Abstracts, 1980 IEEE International Conference on

Plasma Science, University of Wisconsin, Madison,

May 19-21, 1980, IEEE, New York, 1980, p. 107.

65. Oshima, C., Aono, M., Tanaka, T.

Nishitanı, R., and Kawa 1, S., "Low Work Function

and Surface Structure of the $L_{a B}(210)$ Surface

Studied by Angle-Resolved X-Ray Spectroscopy,

Ultraviolet Spectroscopy and Low-Energy Electron

Diffraction," Journal of Applied Physics, Vol. 51,

No. 2, Feb. 1980 , pp. 997-1000.

66. Oshima, C., Aono, M., Tanaka, T.,

Kawar, S., Shrmizu, R., and Hagiwara, H.,

"Thermionic Emission from Single-Crystai $\mathrm{LaB}_{6}$

Tips with [100], [110], [111], and [210] orrentd-

tions," Journal of Applied Physics, Vol. 51,

No. 2, Feb. 1980, pp. 1201-1206.

67. Davis, P. R., Chambers, S. A., and

Swanson, L. W., "The Adsorption of Cesium on

Lanthanum-Hexabor 1 de Surface," Energy to the 21st

Century, Proceedings of the 15 th Intersociety
Energy Conversion Eng ineering Conf erence, Seattle, Wash., Aug. 1980, IEEE, New York, 1980, pp. $2327-2330$

68. "DOE/JPL Advanced Thermionic Technology Program, Progress Report No. 40," Thermo Electron Corporation, Waltham, Mass., TE4237/4247-83-80, July-Aug.-Sept. 1979, p. 64.

69. Storms, E. K., "An Approach to Producing a Successful Bond Between $\mathrm{LaB}_{6}$ and Ta," IEEE Conference Record-Abstracts, 1980 IEEE Internationa 1 Conf erence on Plasma Science, University of Wisconsin, Madison, May 19-21, 1980, IEEE, New York, 1980, p. 107.

70. Babad-Zakhryap ina, A. A., "Characteristics of Diffusion Processes on Condensates, Formed on a Hot Cladding, "Redstone Scientific Information Center, Alabama, Translation, RSIC-676, May 1967, pp. 1-11. (NASA TM X-60158.)

71. Morris, J. F., "Comments on 'Con'tact Diffusion Interaction of Materials with Cladding '," NASA TM $X-2423$, Jan. 1972.

72. Evans, U. R., The Corrosion and Oxidation of Metals, Second Supplementary Volume,

Edward Arnold Publishers, London, 1976.

73. Hurlen, T., "Oxidation of Metals. The

General 0xidation Equation," Acta Chemica Scandinavica, Vol. 13, 1959, pp. 695-704.

74. DOE TEC Program (Executive Summary), IEEE Conference Record-Abstracts, 1980 IEEE International Conference on Plasma Science, University of Wisconsin, Madison, May 19-21, 1980, Sessions 1E, $2 \mathrm{E}, 3 \mathrm{~F}$, and $4 \mathrm{E}$, IEEE, New York, 1980.

75. Goldsmith, A., Waterman, T. E., and Hirschhorn, H. J., Handbook of Thermophysical Properties of Solid Materials, Macmillan, New York, 1961, Vol. 1, pp. 423, 424; Vol. 3, pp. 685-686.

76. Dynatech Report to Consolidated Controls Corporation: The Linear Coefficients of Expansion of 10 Materials, CCS-1 (unpublished data), 1969

(Ref. 2).

77. Merrigan, M. A., Keddy, E. S.,

Dunwoody, W. E., and Lundberg, L., "Ceramic Heat

Pipe Technology," in Reactor Technology, Los

A lamos Scient ific Laboratory, New Mexico,

LA-8403-PR, June 1980.

78. Stephens, J. R., "Materials Technology Assessment for Stirling Engrnes," Highway Vehicle Systems, Department of Energy, Washington, D.C., CONF-771037, Mar. 1978, p. 273.

79. Samsonov, G. V., and Eplk, A. P., Coatings of High-Temperature Materials, Part I, p. 87 , Plenum Press, New York, 1966.

80. Tien, J.K., and Anse 11, G. S., eds.,

Alloy and Microstructural Design, Academic Press, New York, 1976.

81. Sherby, 0. D., and Burke, P. M., "Mechan1cal Behavior of Crystalline Solids at Elevated Temperature," Progress in Material Science,

Vol. 13, No. 1, 1968.

82. Sherby, O. D., "Factors Affecting the High Temperature Strength of Polycrystalline Solids," Acta Metallurglca, Vol. 10, Feb. 1962, pp. 135-147.

83. GTuyas, R. E., and Watson, G. K., "Materials Technology for an Advanced Space Power Nuclear Reactor Concept: Program Summary," NASA TN D-7909, Mar. 1975.

84. Touloukıan, Y. S., ed., Thermophys ical Properties of High Temperature Solid Materials, MacMillan, New York, 1967. 
TABLE I. - SOME SPACE APPLICATIONS FOR METALLIC-FLUID HEAT PIPES.

\begin{tabular}{|c|c|c|}
\hline SYSTEM ELEMENT OR PRIMARY FUNCTION & HEAT-PIPE SERVICE & TEMPERATURE, $\mathrm{K}$ \\
\hline \multirow{2}{*}{\multicolumn{3}{|c|}{$\begin{array}{l}\text { ENERGY SOURCES } \\
\text { Solar Concentrators }\end{array}$}} \\
\hline & & \\
\hline $\begin{array}{l}\text { Materials processing (MP) } \\
\text { (furnaces, ovens...) }\end{array}$ & $\begin{array}{l}\text { Isothermalize receivers and } \\
\text { processors }\end{array}$ & To $>2000$ \\
\hline $\begin{array}{l}\text { Power generation (PG) (thermionic TEC, } \\
\text { TEC topping TEC-T, high-temperature } \\
\text { thermoelectric } \mathrm{H}-\mathrm{T}-\mathrm{TE} \text {, current TE, } \\
\mathrm{H}-\mathrm{T} \text { Brayton } \mathrm{H}-\mathrm{T}-\mathrm{B} \text {, current } \mathrm{B} . . . \text { ) }\end{array}$ & $\begin{array}{l}\text { Isothermalize receivers and } \\
\text { transport thermal power (TTP) }\end{array}$ & To $\sim 1850$ \\
\hline $\begin{array}{l}\frac{\text { Nuc lear Reactors }}{\text { Ultimate space }} \text { reactor }\left(\sim \mathrm{MW}_{\mathrm{e}}{ }^{\prime} \mathrm{s}\right) \\
\quad(\mathrm{TEC}, \text { TEC-T-B...) }\end{array}$ & $\begin{array}{l}\text { Cool reactors, flatten temperature } \\
\text { profiles, TTP, transform TP } \\
\text { densities (TTPD), if required }\end{array}$ & To $>1850$ \\
\hline $\begin{array}{l}\text { JPL out-of-core TEC system }\left(\sim 0.5 \mathrm{MW}_{\mathrm{e}}\right) \\
(\mathrm{TEC}, \mathrm{TEC}-\mathrm{T}-\mathrm{B}, \mathrm{H}-\mathrm{T}-\mathrm{TE}, \mathrm{H}-\mathrm{T}-\mathrm{B} . . .)\end{array}$ & & To $\sim 1675$ \\
\hline $\begin{array}{l}\text { Midpower-range (MPR) reactor }\left(10 \text { to } 250 \mathrm{~kW}_{\mathrm{e}}\right) \\
(\mathrm{TEC}, \mathrm{TE}, \mathrm{H}-\mathrm{T}-\mathrm{B}, \mathrm{B} . \mathrm{.})\end{array}$ & & To $\sim 1400$ \\
\hline $\begin{array}{l}\left.\text { Minireactor (1 to } 10^{\prime} \mathrm{s} \mathrm{kW}_{\mathrm{e}}\right) \\
(\mathrm{TE}, \mathrm{B} \ldots)\end{array}$ & & To $\sim 1300$ \\
\hline$\frac{\text { Radioisotopes }}{\left(\mathrm{To} \mathrm{kW}_{\mathrm{e}} \mathrm{s}\right)(\mathrm{TEC}, \mathrm{H}-\mathrm{T}-\mathrm{TE}, \mathrm{TE} . . .)}$ & $\begin{array}{l}\text { Cool and isothermalize radioisotopes, } \\
\text { TTP (TTPD) }\end{array}$ & To $\sim 1500$ \\
\hline $\begin{array}{l}\text { THERMAL-TO-ELECTRIC CONVERTERS } \\
\text { Thermal-Power Input }\end{array}$ & & \\
\hline $\begin{array}{l}\text { TEC emitters } \\
\text { TE hot shoes }\end{array}$ & $\begin{array}{l}\text { TTP, TTPD, heat, isothermalize } \\
\text { TTP, heat, isothermalize }\end{array}$ & To $>1800$ \\
\hline New materials & & To $\sim 1600$ \\
\hline $\begin{array}{l}\text { Current materials } \\
\text { Best possibility } \\
\text { Ready availability }\end{array}$ & & $\begin{array}{l}\sim 1300 \\
\sim 1000\end{array}$ \\
\hline
\end{tabular}


TABLE I. - Continued. SOME SPACE APPLICATIONS FOR METALLIC-FLUID HEAT PIPES.

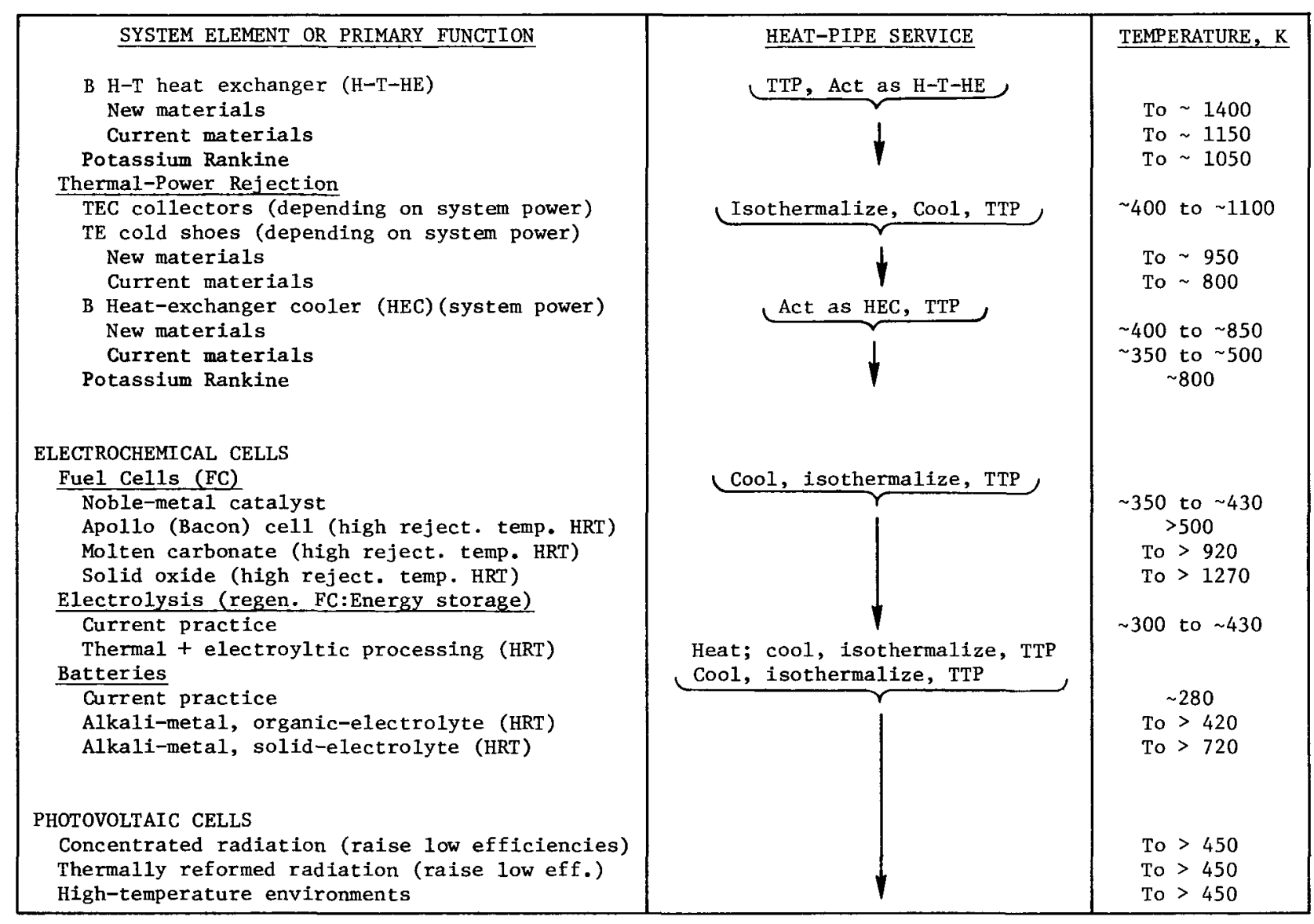


TABLE I. - Concluded. SOME SPACE APPLICATIONS FOR METALLIC-FLUID HEAT PIPES.

\begin{tabular}{|c|c|c|}
\hline 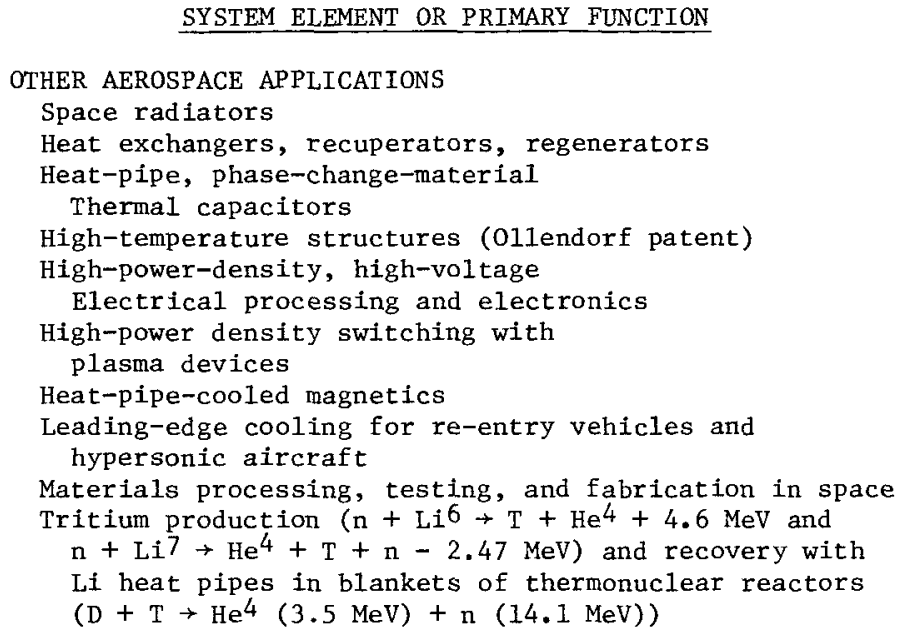 & HEAT-PIPE SERVICE & $\begin{aligned} & \text { To }>1100 \\
& \text { To }>1850 \\
& \text { To }>1300 \\
& \text { To } \sim 350 \\
& \mathrm{~T}_{\mathrm{E}}^{\prime} \text { 's to }>2000 \\
& \mathrm{~T}_{\mathrm{C}} \text { 's to }>1000 \\
& \text { To }>1100 \\
& \text { To }>2000 \\
& \\
&> \\
&>1400\end{aligned}$ \\
\hline
\end{tabular}




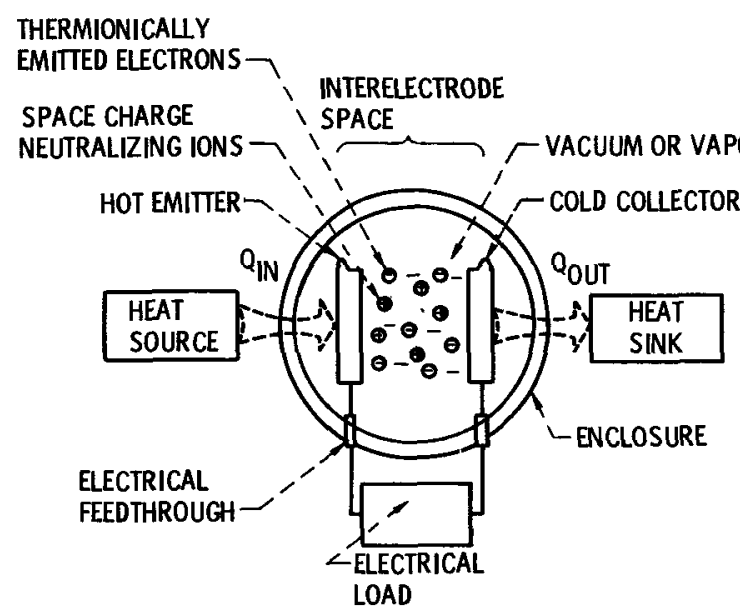

THERMIONIC-ENERGY-CONVERTER ELECTRONS

ESCAPE THE HEATED EMITTER,

PASS THROUGH THE INTERELECTRODE GAP,

ENTER THE COOLED COLLECTOR,

DEVELOP VOLTAGE ACROSS THE ELECTRODES,

FLOW BACK TO THE EMITTER EXTERNALLY,

PERFORM ELECTRICAL WORK, AND

RECYCLE CONTINUOUSLY.

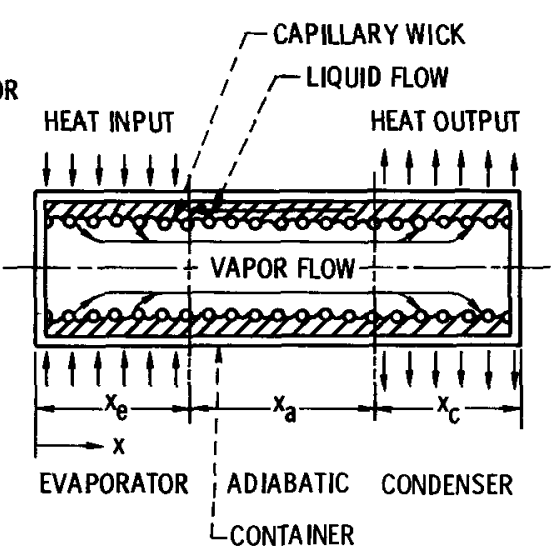

THE HEAT-PIPE WORKING FLUID

VAPORIZES IN THE HEATED "EVA PORATOR," FLOWS AS A VAPOR THROUGH THE "ADIABATIC SECTION,"

GNES UP ITS HEAT OF CONDENSATION IN THE COOLED "CONDENSER"

FLOWS AS A LIQUID BACK TO THE EVAPORATOR THROUGH THE "WICK" ARTERIES,

MOVES TO THE VAPORIRING SURFACE THROUGH THE WICK CAPILLARIES,

AND RECYCLES CONTINUOUSLY.

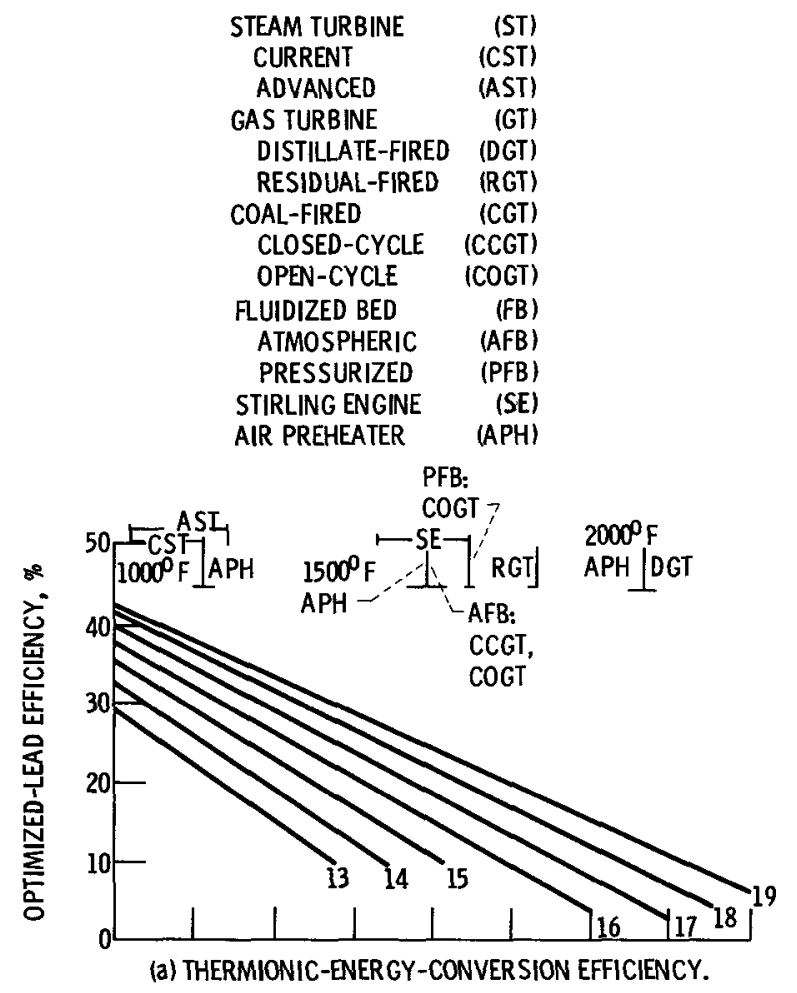

Figure 1. - TEC and heat-pipe cycles.

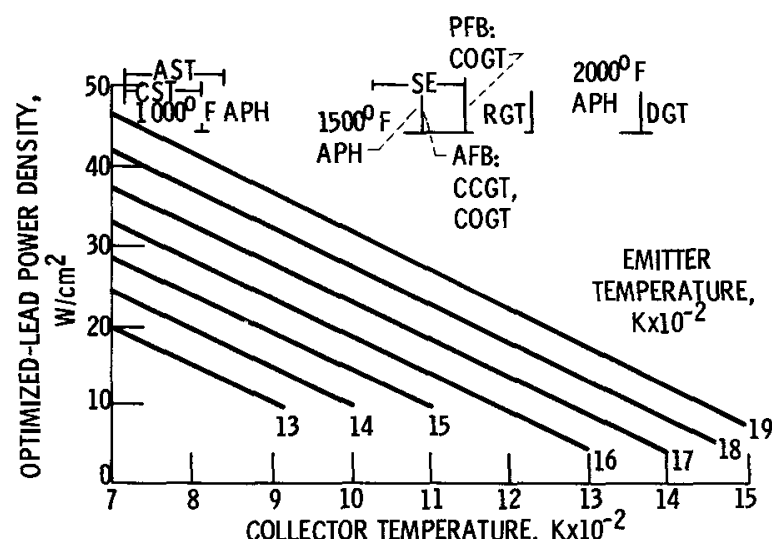

(b) THERMIONIC-ENERGY-CONVERSION POWER DENSITY.

Figure 2 - Performance and topping temperatures for thermionic energy conversion with $30 \mathrm{~A} / \mathrm{cm}^{2}, 10 \%$ back emission and negligible interelectrode losses. 


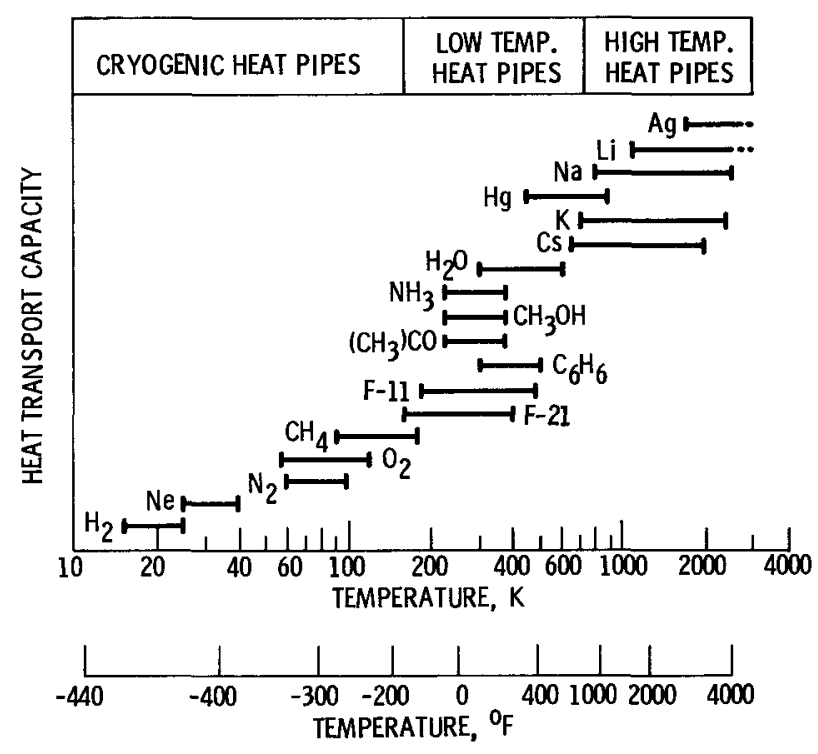

Figure 3. - Heat-pipe operating ranges.

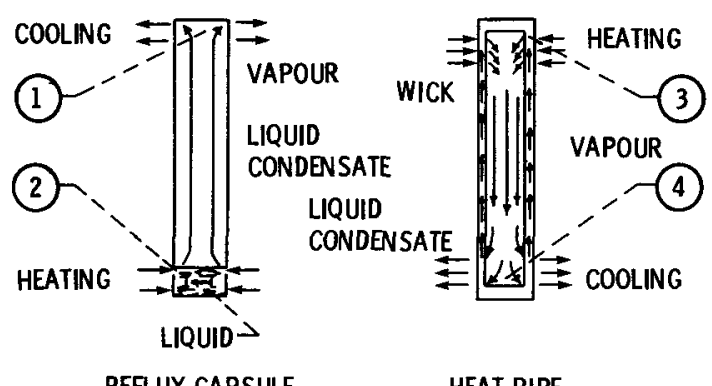

REFLUX CAPSULE

HEAT PIPE

REFLUX-CAPSULE TEST FLUIDS

(1) VAPORIZE, SWEEP NONCONDENSIBLE CORROSION PRODUCTS TO CAPSULE TOPS, CONDENSE,

(2) FORM, DISSOLVE, AND DRA IN NONVOLATILE CORROSION PRODUCTS TO CAPSULE BOTTOMS, DILUTING NONVOLATILE CORROSION PRODUCTS IN TEST-LIQUID POOLS.

\section{HEAT-PIPE WOR KING FLUIDS}

(3) IN CONTRAST, TRANSPORT DISSOLVED CORROSION PRODUCTS THROUGH WICK ARTERIES TO EVAPORATORS, MOVE TO EVAPORATING SURFACES THROUGH WICK CAPIUARIES, VAPORIZE, LEAVING CONTINUOUSLY CONCENTRATING NONVOLATILE CORROSION PRODUCTS IN EVAPORATOR WICKS

(4) THEN SWEEP NONCONDENSIBLE CORROSION PRODUCTS TO CONDENSER ENDS, LIQUEFY, AND RECYCLE.

CAPSULE, COUPON, OR ORDINARY -FLOW METHODS DO NOT APPROXIMATE HEAT-PIPE LIFE TESTING.

BUT A SUTAABIF CYLINDRIC SCREEN CHANGES AN INEFFECTNE CAPSULE INTO A HEAT-PIPE FOR EFFECTNE, ECONOMICAL LIFE TESTING.

Figure 4. - Heat-pipe materials compatibility: life testing. 


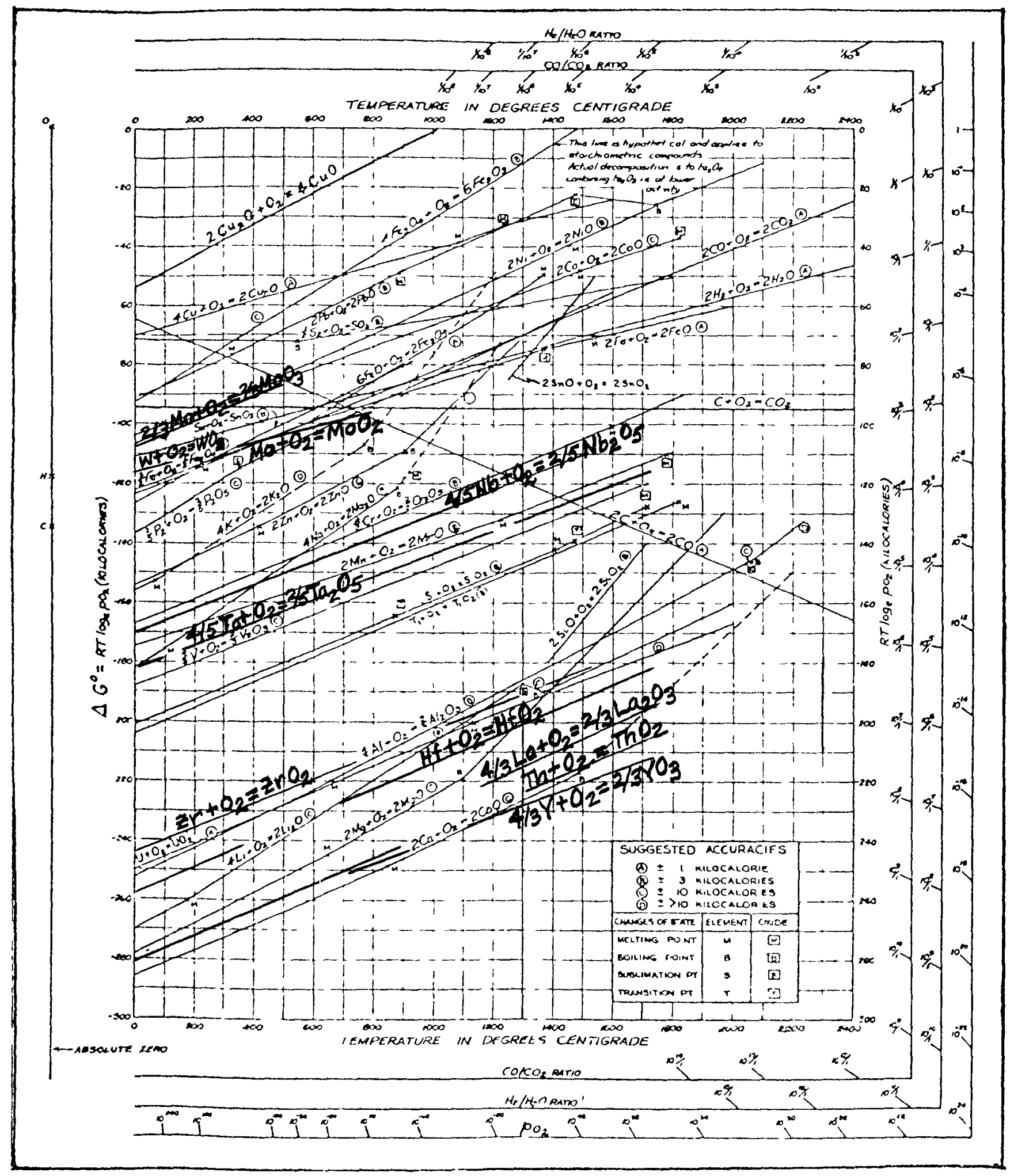

1ig. 5 Fiee-ene'gi dara for ovde formation (after Richardson and Jeffes, 1948) 10

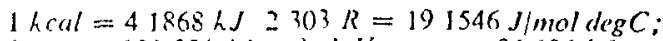

$1 \mathrm{~atm}=101325 \mathrm{~h} \backslash \mathrm{Im}^{\prime}, \mathrm{I} \mathrm{V}$ cqum. $=96606 \mathrm{~kJ}$.

(Refs. 38 to 41.) (Courtesy of American Society for Meta1s.) 


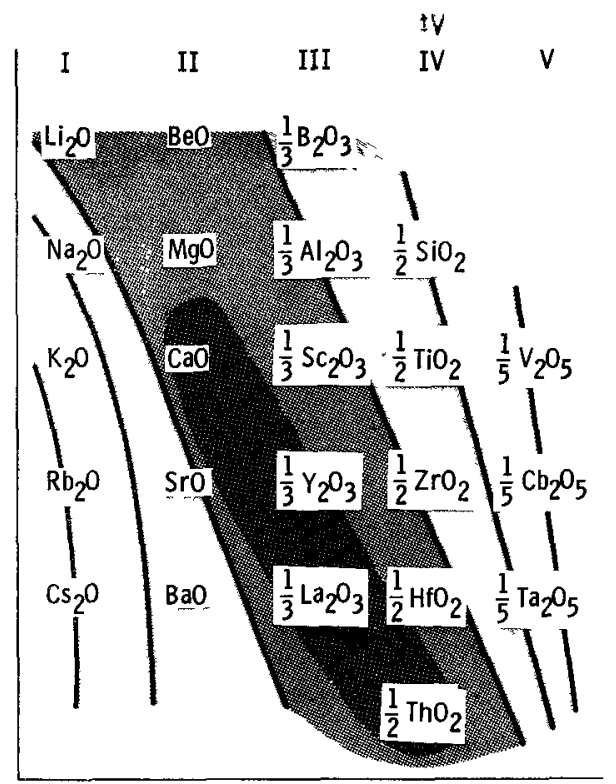

Figure 6. - Stability relationships of refractory oxides. Solid lines represent constant standard free energy of formation from the elements. The darkest area is the region of greatest stability (ref. 42).

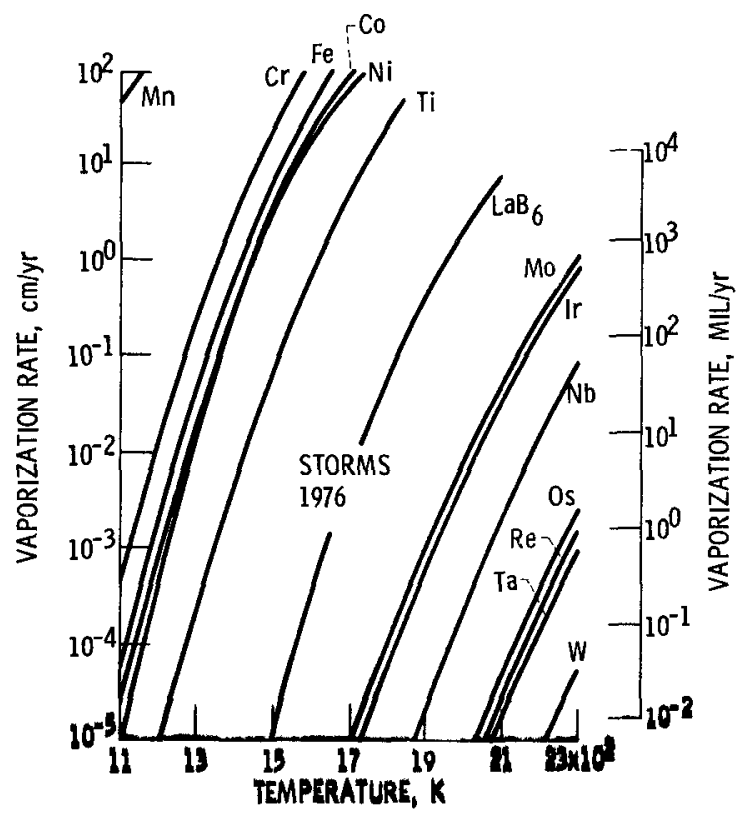

Figure $y_{\text {s }}$ - Vaporizution of puru motals and lenthanum hexalsoride, 
RELATIVE WEIGHT PARAMETER

(BASED ON ASME PRESSURE VESSEL CODE)

FOR HIGH-PRESSURE HEAT-PIPE ENVELOPES

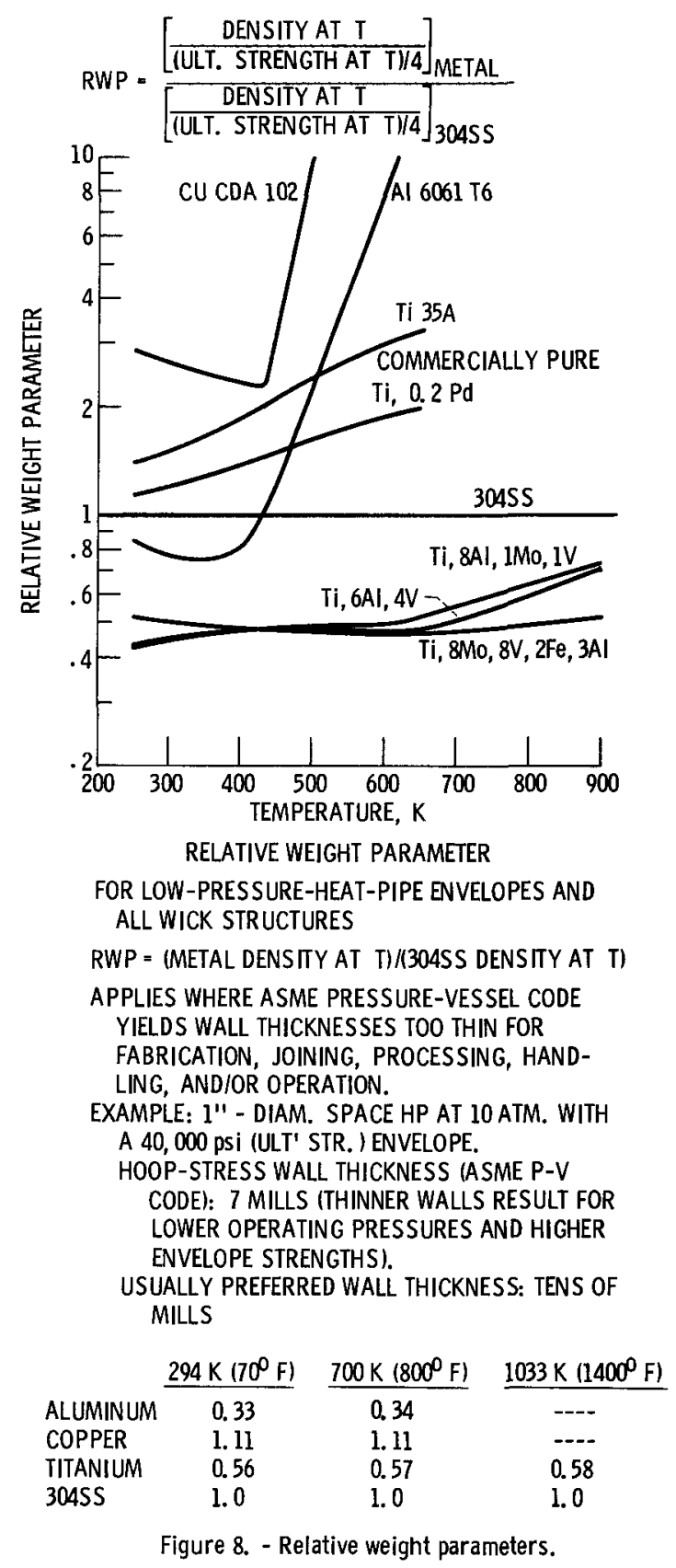




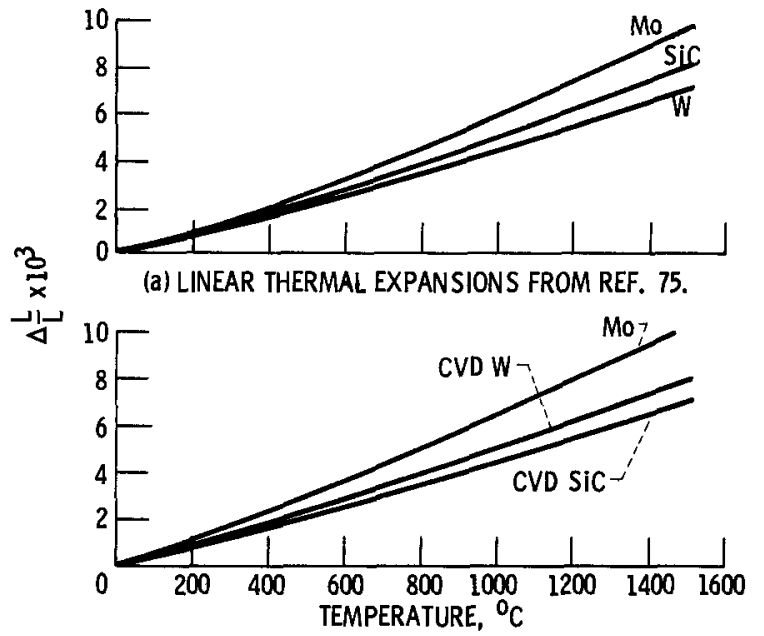

(b) LINEAR THERMAL EXPANSIONS FROM REF. 76.

Figure 9. - Linear thermal expansions for Mo, $\mathrm{W}$, and Sic from ref. 2.

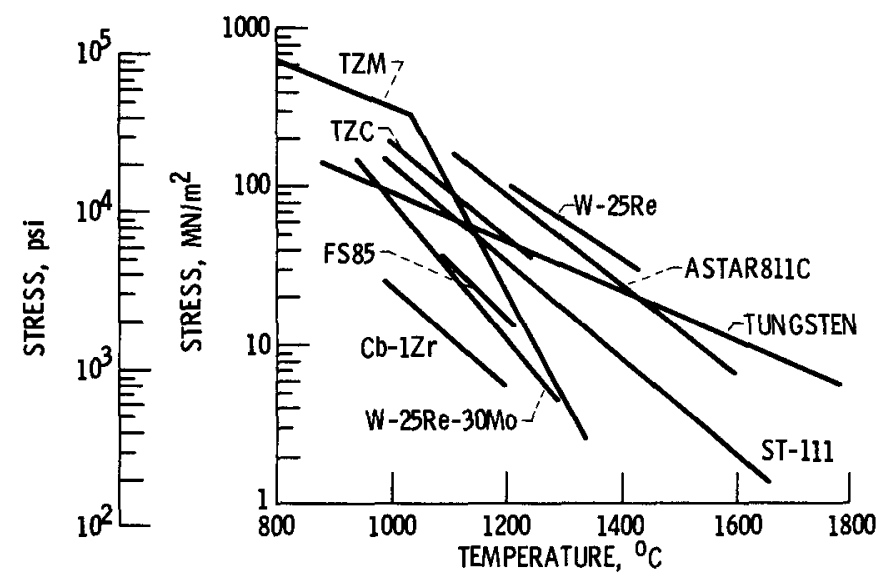

Figure 10. - Creep strength of some refractory metals and alloys for 1 percent creep in 10000 hours. 


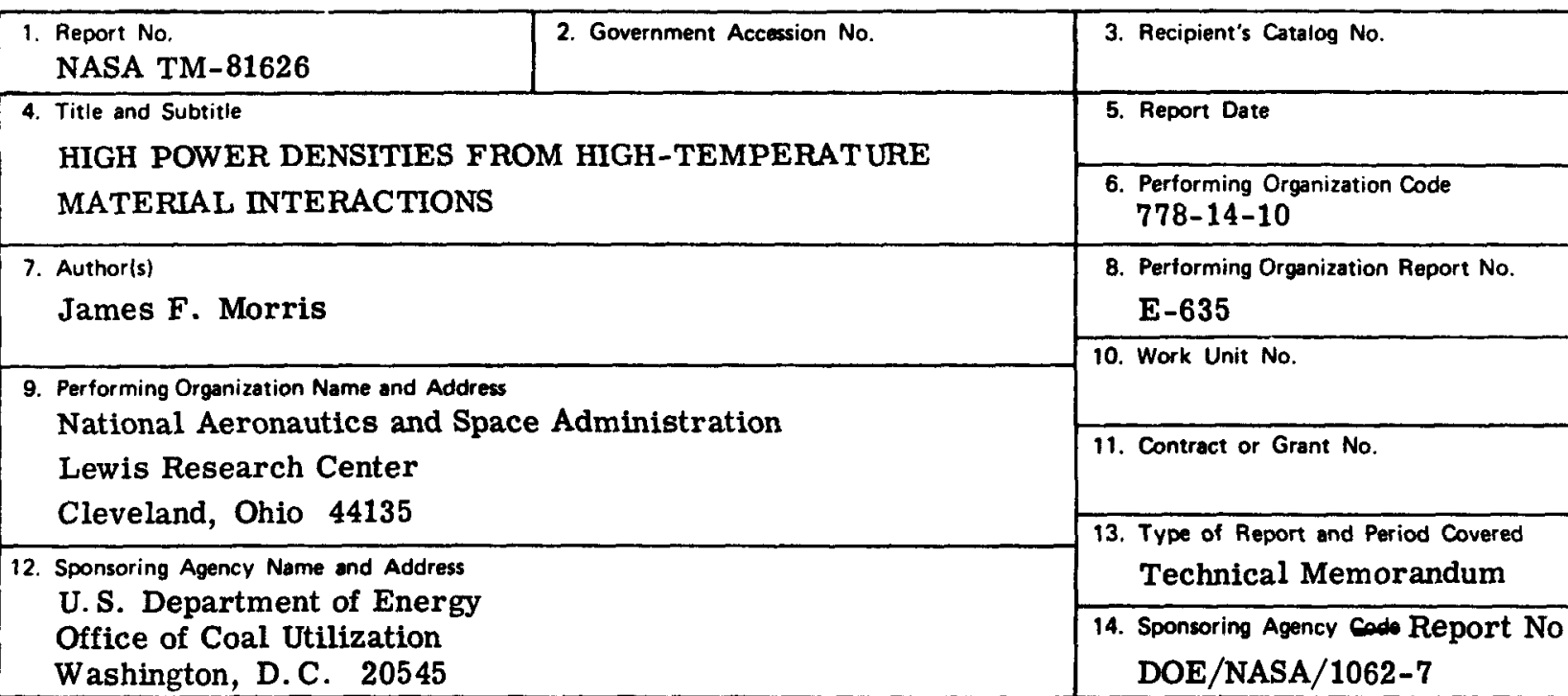

15. Supplementary Notes

Prepared under Interagency Agreement EC-77-A-31-1062. Prepared for Sixteenth Thermophysics Conference, High Temperature Material Session, sponsored by American Institute of Aeronautics and Astronautics, Palo Alto, California, June 23-25, 1981.

16. Abstract

Thermionic energy conversion (TEC) and metallic-fluid heat pipes (MFHPs) offer important and unique advantages in terrestrial and space energy processing. And they are well suited to serve together synergistically. TEC and MFHPs operate through working-fluid vaporization, condensation cycles that accept great thermal power densities at high temperatures. TEC and MFHPs have apparently simple, isolated performance mechanisms that are somewhat similar. And they also have obviously difficult, complected material problems that again are somewhat similar. Intensive investigation reveals that aspects of their operating cycles and material problems tend to merge: "In short, high-temperature material effects determine the level and lifetime of ... performance." Simplified equations verify the preceding statement for TEC and MFHPs. Material properties and interactions exert primary influences on operational effectiveness. And thermophysicochemical stabilities dictate operating temperatures which regulate the thermoemissive currents of TEC and the vaporization flow rates of MFHPs. Major hightemperature material problems of TEC and MFHPs have been solved. These solutions lead to productive, cost-effective applications of current TEC and MFHPs -- and point to significant improvements with anticipated technological gains.

17. Key Words (Suggested by Author(s) Thermionic energy conversion (TEC); Metallic-fluid heat pipes; High temperatures; High power densities; High-temperature materials; Terrestrial and space applications
18. Distribution Statement Unclassified - unlimited STAR Category 75

DOE Category UC-90f

19. Security Classif. (of this report)

Unclassified

20. Security Classif. (of this page) Unclassified

21. No. of Pages

22. Price*

${ }^{*}$ For sale by the National Technical Information Service, Springfield, Virginia 22161 